\title{
REVIEW
}

Open Access

\section{Perfusion fixation in brain banking: a systematic review}

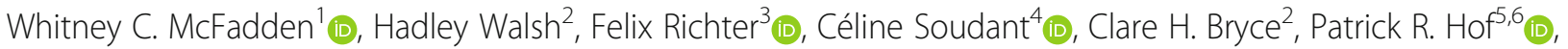
Mary Fowkes ${ }^{2}$, John F. Crary ${ }^{2,5,6,7}$ and Andrew T. McKenzie ${ }^{1,7^{*}}$ (D)

\begin{abstract}
Background: Perfusing fixatives through the cerebrovascular system is the gold standard approach in animals to prepare brain tissue for spatial biomolecular profiling, circuit tracing, and ultrastructural studies such as connectomics. Translating these discoveries to humans requires examination of postmortem autopsy brain tissue. Yet banked brain tissue is routinely prepared using immersion fixation, which is a significant barrier to optimal preservation of tissue architecture. The challenges involved in adopting perfusion fixation in brain banks and the extent to which it improves histology quality are not well defined.
\end{abstract}

Methodology: We searched four databases to identify studies that have performed perfusion fixation in human brain tissue and screened the references of the eligible studies to identify further studies. From the included studies, we extracted data about the methods that they used, as well as any data comparing perfusion fixation to immersion fixation. The protocol was preregistered at the Open Science Framework: https://osf.io/cv3ys/.

Results: We screened 4489 abstracts, 214 full-text publications, and identified 35 studies that met our inclusion criteria, which collectively reported on the perfusion fixation of 558 human brains. We identified a wide variety of approaches to perfusion fixation, including perfusion fixation of the brain in situ and ex situ, perfusion fixation through different sets of blood vessels, and perfusion fixation with different washout solutions, fixatives, perfusion pressures, and postfixation tissue processing methods. Through a qualitative synthesis of data comparing the outcomes of perfusion and immersion fixation, we found moderate confidence evidence showing that perfusion fixation results in equal or greater subjective histology quality compared to immersion fixation of relatively large volumes of brain tissue, in an equal or shorter amount of time.

Conclusions: This manuscript serves as a resource for investigators interested in building upon the methods and results of previous research in designing their own perfusion fixation studies in human brains or other large animal brains. We also suggest several future research directions, such as comparing the in situ and ex situ approaches to perfusion fixation, studying the efficacy of different washout solutions, and elucidating the types of brain donors in which perfusion fixation is likely to result in higher fixation quality than immersion fixation.

Keywords: Brain banking, Perfusion fixation, Immersion fixation, Brain perfusion, Histology quality

\footnotetext{
* Correspondence: andrew.mckenzie@icahn.mssm.edu

'Department of Psychiatry, Icahn School of Medicine at Mount Sinai, One

Gustave L. Levy Place, New York, NY 10029, USA

${ }^{7}$ Neuropathology Brain Bank and Research Core, Icahn School of Medicine at

Mount Sinai, One Gustave L. Levy Place, New York, NY 10029, USA

Full list of author information is available at the end of the article
}

(c) The Author(s). 2019 Open Access This article is distributed under the terms of the Creative Commons Attribution 4.0 International License (http://creativecommons.org/licenses/by/4.0/), which permits unrestricted use, distribution, and reproduction in any medium, provided you give appropriate credit to the original author(s) and the source, provide a link to the Creative Commons license, and indicate if changes were made. The Creative Commons Public Domain Dedication waiver (http://creativecommons.org/publicdomain/zero/1.0/) applies to the data made available in this article, unless otherwise stated. 


\section{Introduction}

Much of our understanding of the pathophysiology of human diseases of the brain is derived from studies on postmortem human brain tissue [10, 15, 49]. The knowledge resulting from human postmortem brain research emphasizes the importance of collecting and banking the brains of human donors in as close to a life-like state as possible to allow for an accurate study of pathophysiologic processes. However, the methods used for banking human brain tissue are often not the methods that lead to the highest tissue quality. Therefore, there is a critical need to develop and optimize methods used to preserve human brain tissue. This will enable the full application of emerging three-dimensional brain tissue mapping methods that rely on the high-fidelity preservation of tissue architecture across large regions. These include spatial biomolecular profiling methods such as in situ transcriptomics [97], long-range circuit-tracing techniques using tissue clearing and immunostaining [72], and large-volume ultrastructural studies such as electron microscopy-based connectomics [101].

The two major methods for preparing human brain tissue for long-term storage are cryopreservation of small tissue blocks and chemical fixation of the tissue by crosslinking agents such as aldehydes [68, 80, 94]. Fresh-frozen tissue is essential for the study of brain biochemistry and has become especially important for brain banks over the past several decades, in part due to the flourishing of biochemical and molecular biological assays that require unfixed tissue $[15,49]$. However, there are some studies, including ones that query cellular and tissue morphology, that are best performed on fixed tissue. There are two major methods for fixation: immersion fixation, which refers to placing the brain in a chemical bath that includes fixatives and waiting for the chemicals to diffuse into the brain tissue, and perfusion fixation, which refers to cannulating some part of the vasculature system and then driving fixative-containing fluid through the vessels, where it then travels out of circulation into the tissue. In human postmortem brain tissue, it has been estimated that it can take 20 to 46 days for a sufficient amount of formaldehyde to diffuse to the innermost parts of a brain hemisphere and begin fixation [21]. During this time, tissue in the inner regions of the brain will undergo microbial degradation, autolysis, breakdown of cellular membranes, and stochastic diffusion of molecules. As a result, immersion fixation causes gradients in fixation quality, whereby the surface regions where the fixation was initially applied has substantially better tissue preservation quality than deeper regions $[5,61]$. However, in addition to simplicity, one upside of immersion fixation is that it does not rely on an intact neurovascular system, so the outermost surface millimeters of the brain tissue could undergo better fixation, especially if there are any clots occluding blood vessels.
Perfusion fixation of the brain has been performed in animal models for many decades as a way to preserve tissue integrity in a more robust and reliable manner [48]. Several investigators have compared perfusion fixation to immersion fixation for brain and vascular system fixation quality in animals, and these studies have generally found that tissues are substantially better preserved by perfusion fixation than immersion fixation beyond the first few millimeters, as measured by less displacement of neuropil, fewer vacuolar changes, and other metrics $[17,31,50,71]$. While perfusion fixation is the gold standard for processing brain tissue prior to subsequent investigations in animals, it is not as commonly performed in contemporary human brain banking. Instead, one of the most common contemporary approaches to bank human brain tissue is to split the brain into two halves by making an incision at the midsagittal plane, and preserve one half via immersion fixation, and the other half via cryopreservation or freezing of small dissected portions of the brain [68, 80, 94]. Reasons that perfusion fixation is not as commonly used in banking human brain tissue include tissue and blood vessel damage that often occur prior to death and lack of access to equipment and relevant expertise by those procuring brain tissue. However, differences in fixation quality between immersion and perfusion fixation have been found to account for apparent differences in the nervous systems of humans and animals [54].

In this systematic review, we aimed to identify studies that have performed perfusion fixation for human brain tissue preservation and performed a qualitative synthesis of their methodologies. The major research questions we set out to answer were what methods have been used for human brain perfusion fixation and how does perfusion fixation compare to immersion fixation in terms of preservation outcomes. We attempted to contextualize the choices investigators made with reference to other literature, such as the literature on perfusion fixation of animal brains. The rationale of this review is to present a unified and accessible source of the experiences of researchers who have previously employed perfusion fixation in human brain tissue, for investigators who themselves may be interested in using the method. While systematic reviews have been published on the use of cadaver reperfusion for surgical training including neurosurgery training $[8,33,100]$, to the best of our knowledge there has not been a review of methods for perfusion fixation in human brain tissue preservation. Our review revealed that while the method has been used since the 1960s, there is no clear trend of an increased use of this method in recent years. In terms of outcomes, the available evidence suggests that perfusion fixation probably leads to equivalent or improved subjective histology quality compared to immersion fixation of relatively large volumes of brain tissue, in a shorter amount of time. 


\section{Methods}

The systematic review was conducted following PRISMA (Preferred Reporting Items for Systematic Reviews and Meta-Analyses) guidelines. The protocol for the review and updated versions of it the can be found at Open Science Framework (https://osf.io/cv3ys/). The PRISMA checklist is also available (Additional file 1). During the review process, there were several changes made between the original protocol and the methods we employed. These are noted below in the section "Differences between the protocol and the review."

\section{Search methods}

We searched Embase Classic+Embase (1947 to February 2019), Medline All (1946 to February 2019), PubMed, and Scopus without language or date restriction (see Additional file 2 for detailed searches). The database search strategies include a combination of subject headings and keywords. To identify additional publications that are missed by these searches, we screened the references and citing articles (as identified by Scopus) of all included articles.

\section{Eligibility criteria}

Any scholarly publication such as a journal article or textbook chapter that describes methods for perfusion fixation of the human brain was included. To be included, a study only needs to report on the perfusion fixation of human brain tissue and describe the methods for doing so; it does not need to be primarily about the process of perfusion fixation of the human brain. Fixation was defined as the use of a chemical substance or mixture of chemicals designed to preserve the tissue architecture and molecules in their lifelike state. Perfusion fixation was defined as using the vascular system in order to distribute fixatives throughout brain tissue. Studies on human brain tissue of any age were included. Studies were included if they perfuse the whole brain, only part of the brain such as a hemisphere, or a particular brain region. Studies that are performed by the same investigators and describe the same methods without substantive changes were considered together as one study, referred to by the study with the most detailed description of the methods. Studies written in any language were considered. If not written in English, studies were translated with the help of online tools such as Google Translate and Yandex Translate.

Although our focus is on the use of perfusion fixation for brain banking, our search strategy allowed us to identify articles that used perfusion fixation of postmortem human brain tissue for any type of research study, rather than only brain banking in particular. We used this approach to try to increase the pool of studies using perfusion fixation on human brain tissue from which we could learn and draw conclusions.

\section{Study selection}

Using the online software Covidence, one reviewer (A.M.) screened the titles and abstracts identified by the searches and screened them in for further review on the basis of the eligibility criteria. Subsequently, two individuals (W.M. and A.M.) reviewed the full text of these articles, determined which articles met criteria for inclusion, and noted the exclusion reason(s) for the other articles. Disagreements were resolved by a consensus meeting.

\section{Data collection}

For all included studies, at least two reviewers (H.W., F.R., C.B., and/or A.M.) extracted data variables about the methods and outcomes related to human brain perfusion fixation (see Additional file 3 for the questionnaire). In the case that there was disagreement between these reviewers that could not be addressed by further assessment of the manuscript by one of the reviewers (A.M.), then an additional reviewer (W.M.) was referred to in order to establish a decision. The data variables that were extracted are: number of perfusion- and immersion-fixed brains; exclusion criteria that would prevent the use of perfusion fixation for fixing brain tissue, for example long postmortem interval or vascular disease; tissue processing prior to vascular access; vessels accessed for perfusion; prefixative infusion; fixative mixture and buffer; time for perfusion; amount of fluid perfused; perfusion pressure; tissue processing before postfixation; postfixation procedure for perfusion fixed brains; tissue processing and storage procedure for perfusion fixed brains; metric(s) for fixation quality; downstream assays used or suggested; metric(s) for comparison to immersion fixation; and outcomes in comparison to immersion fixation. In the case that the variables were likely performed, known, or measured by the study authors but not reported, we attempted to contact the corresponding author(s) of the study via email and inquire about the variables.

\section{Study appraisal}

Studies that present an explicit comparison between perfusion fixation and immersion fixation and/or between methods of perfusion fixation were assessed using the Joanna Briggs Institute (JBI) critical appraisal tool for quasi-experimental studies [91]. To harmonize the study appraisal tool with the downstream Cochrane tool for grading outcomes by the risk of bias of the studies included, we made one change to this checklist: we added an explicit question about the use of blinding by each study in the outcome assessment (Additional file 3). To maintain the same number of questions, we removed question \#1 about clarity between "cause" and "effect," which is not relevant to the experimental designs in the 
studies that we are assessing. For each of the studies, the number of "yes" answers out of the total number of questions was counted. "Not applicable" criteria were excluded, while criteria that were "unclear" were counted equivalently to a "no," or not meeting the criteria. Studies were given an overall quality rating of "low" if $0-33 \%$ of the JBI questions were "yes," "medium" if 34-66\% of the criteria were "yes," and "high" if $67 \%$ or more of the criteria were "yes." Low quality studies were excluded from the outcomes grading step, as has been performed by a different systematic review using the JBI criteria [84]. The study quality metrics were assessed by at least two reviewers (H.W., F.R., C.B., and/or A.M.). In the case that there was a disagreement between these reviewers, an additional reviewer (W.M.) decided. The study quality metrics were taken into account when considering the strength of the evidence in the outcomes that they report.

\section{Qualitative data analysis}

A qualitative survey of the different methods that have been reported for perfusion fixation in human brain banking was performed. Where possible, comparisons were made between the reported outcomes of immersion compared to perfusion fixation for brain banking. Because the studies were not expected to measure or report quantitative data on fixation quality, we performed a qualitative synthesis rather than a quantitative meta-analysis. Outcomes were evaluated using the GRADE (Grading of Recommendations, Assessment, Development, and Evaluations) method [75]. Each outcome between perfusion and immersion fixation was considered separately and had its own row in the summary of findings table. There were two outcomes assessed: (1) the subjective histology quality following either immersion or perfusion fixation and (2) the subjective histology quality following either immersion or perfusion fixation and after long-term storage in fixative. There are four possible levels for outcome quality in the GRADE method: high, moderate, low, and very low. In the GRADE method, all results derived from randomized trials start with a grade of high, while results derived from non-randomized studies start with a grade of low. Next, these grades were downgraded by one level for serious concerns or two levels for very serious concerns about risk of bias, inconsistency, indirectness, imprecision, and publication bias. They were upgraded by one level for large magnitudes of effect, for a dose-response relationship, or when the effects of all plausible confounds would go against the effect seen. The risk of bias for each study was assessed as a part of the JBI critical appraisal checklist. For example, confounding bias was assessed by the JBI checklist question about whether the participants in any comparisons were similar. Two reviewers (W.M. and A.M.) worked independently to evaluate the quality of evidence for each outcome and then came to a consensus decision.

\section{Differences between the protocol and the review}

We note the following changes from the preregistered protocol. First, to grade the outcomes identified in the studies between perfusion and immersion fixation, we added these components to the questionnaire and methods. Critical appraisal of studies was only performed for studies that included a comparison between perfusion and immersion fixation, as the other studies were descriptive. In order to maintain the same appraisal criteria consistently across randomized and non-randomized experimental studies, all of the studies that compared perfusion fixation to immersion fixation or compared methods of perfusion fixation were critically appraised using the JBI checklist for quasi-experimental studies. Because it was not possible to adequately appraise studies that made only an implicit comparison between perfusion and immersion fixation, we changed the protocol so that only studies that made an explicit comparison were included in this section of the review.

One assumption made during the data extraction phase was that if the article described performing perfusion fixation on "brains" following autopsy, unless otherwise noted the study was assumed to have removed the brain from the skull prior to perfusion fixation and therefore was classified as "ex situ." We also found that many of the studies listed brain donor exclusion criteria that were independent of the use of perfusion fixation but specific to their study needs, such as the absence of neurologic or psychiatric disease in a study of neurotypical brain tissue. Therefore, we attempted to identify brain donor exclusion criteria that were particular to the use of perfusion fixation.

After the data extraction process, we decided that the studies, methods, and outcomes for the comparisons between methods of perfusion fixation identified were too few and heterogeneous to provide any meaningful qualitative synthesis across studies. Therefore, we did not perform outcomes grading for comparisons between methods of perfusion fixation. We also did not identify any studies that compared how the perfusion fixation and immersion fixation approaches differed in fixation quality based on the brain tissue characteristics, so this was also not addressed. The outcomes selected for comparison between immersion and perfusion fixation were determined after the data extraction stage on the basis of the available data, and were not included in the original protocol. Finally, we also decided that studies that were deemed "low" quality based on our predetermined summary threshold of JBI quality metrics would not be included in the outcomes grading. 
Format of this review

The first part of this review section will list the methods for perfusion fixation used by the included studies, while the second part will summarize any outcomes of comparisons between perfusion and immersion fixation.

\section{Results and discussion}

\section{Characteristics of included studies}

We screened 4489 abstracts, 214 full-text publications, and identified 35 studies that met our inclusion criteria, which collectively reported on the perfusion fixation of 558 human brains (Fig. 1). Reasons for full-text exclusion decisions were that: no humans were studied (i.e. only animal models; 87 studies), no changes were made from previous methods (i.e., another article that used the same methods was already was included; 47 studies), no perfusion fixation was performed in human tissue (e.g., perfusion fixation in animals and immersion fixation in humans; 42 studies), and brain tissue was not studied (e.g., only inner ear tissue studied; 3 studies).
The studies were classified into three types: histology, e.g., for neuropathologic examination, forensic examination, or to study biomolecular and morphologic mechanisms of human brain function and disease; gross anatomical study, e.g. of white matter anatomy; or surgical training, e.g. for neurosurgery (Table 1). Of the articles focused on histology, there was an additional distinction between studies focused primarily on blood vessels (e.g., Lin et al. [57], Böhm [12], Masawa et al. (1993) [59], Shinkai et al. [81], Feekes et al. [28]) and studies focused primarily on brain parenchyma (e.g., Beach et al. [7], Halliday et al. [35], Welikovitch et al. [99], Donckaster et al. [24]). By plotting the methods used and the number of brains reported as perfused in each study, it is possible to examine qualitative trends over time, such as a relative decrease in the use of the in situ approach for histology studies (Fig. 2).

\section{Methods of perfusion fixation for brain banking Approach to perfusion fixation}

A major difference among studies that emerged was whether the investigators performed the perfusion

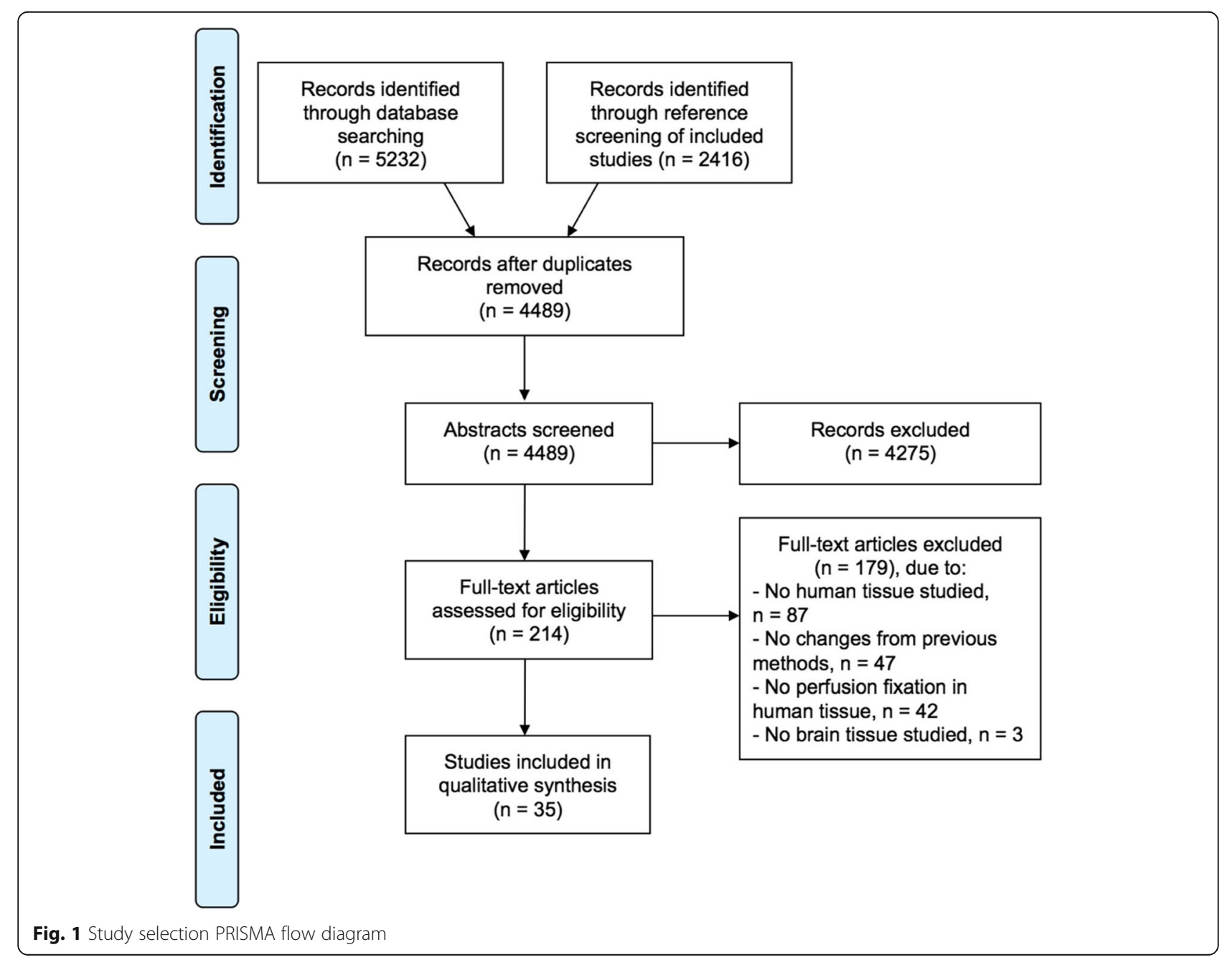


Table 1 General characteristics of included studies

\begin{tabular}{|c|c|c|c|c|}
\hline Study & Country & Study type & Approach & Number of perfusion-fixed brains \\
\hline Adickes 1996 [2] & United States & Histology & Ex situ, whole brain & NR \\
\hline Adickes 1997 [1] & United States & Histology & Ex situ, one hemisphere & 4 \\
\hline Alvernia 2010 [3] & France, United States & Surgical training & In situ, head separated & 20 \\
\hline Beach 1987 [7] & Canada, Japan & Histology & Ex situ, whole brain & 4 \\
\hline Benet 2014 [9] & United States & Surgical training & In situ, head separated & 12 \\
\hline Böhm 1983 [12] & Germany & Histology & In situ, thoracic dissection & $>=50$ (histology for 12) \\
\hline Coveñas 2003 [20] & Spain & Histology & Ex situ, whole brain & 4 \\
\hline de Oliveira 2012 [23] & Brazil & Histology & Ex situ, one hemisphere & 14 \\
\hline Donckaster 1963 [24] & Chile, Uruguay & Histology & In situ, neck dissection & 103 \\
\hline Feekes 2005 [28] & United States & Gross anatomy & Unclear & 40 \\
\hline Grinberg 2008 [34] & Brazil & Histology & Ex situ, whole brain & 32 \\
\hline Halliday 1988 [35] & Australia & Histology & Ex situ, whole brain & 5 \\
\hline Huang 1993 [40] & Australia & Histology & Ex situ, whole brain & 5 \\
\hline Insausti 1995 [42] & Spain & Histology & Ex situ, whole brain & 12 \\
\hline Istomin 1994 [43] & Russia & Histology & Ex situ, whole brain; In situ, neck dissection & NR \\
\hline Kalimo 1974 [45] & United States & Histology & In situ, neck dissection & 5 \\
\hline Latini 2015 [53] & Sweden & Gross anatomy & In situ, neck dissection & 10 \\
\hline Lin 2000 [57] & Japan & Histology & Unclear & NR \\
\hline Lyck 2008 [58] & Denmark & Histology & In situ, unclear approach & 5 \\
\hline Masawa 1993 [59] & Japan & Histology & Ex situ, whole brain & 18 \\
\hline Masawa 1994 [60] & Japan & Histology & Ex situ, whole brain & 121 \\
\hline McGeer 1988 [62] & Canada & Histology & Ex situ, whole brain & NR \\
\hline McKenzie 1994 [64] & United States & Histology & In situ, neck dissection & 2 \\
\hline Nakamura 1991 [69] & Japan & Histology & Ex situ, whole brain & 4 \\
\hline Pakkenberg 1966 [70] & Denmark & Histology & In situ, unclear approach & 1 \\
\hline Sharma 2006 [79] & United Kingdom & Histology & Ex situ, whole brain & 36 \\
\hline Shinkai 1976 [81] & Japan & Histology & Ex situ, whole brain & 9 \\
\hline Sutoo 1994 [85] & Japan & Histology & Ex situ, whole brain & 2 \\
\hline Suzuki 1979 [86] & Japan & Histology & Ex situ, whole brain & 19 \\
\hline Tanaka 1975 [87] & United States & Histology & In situ, neck dissection & 1 \\
\hline Torack 1990 [90] & United States & Histology & Ex situ, whole brain & 4 \\
\hline Turkoglu 2014 [92] & United States & Surgical training & In situ, head separated & NR \\
\hline von Keyserlingk 1984 [93] & Germany & Histology & In situ, neck dissection & 4 \\
\hline Waldvogel 2006 [96] & New Zealand & Histology & Ex situ, whole brain; Ex situ, single hemisphere & NR \\
\hline Welikovitch 2018 [99] & Hungary, Canada & Histology & Ex situ, whole brain & 12 \\
\hline
\end{tabular}

For study type, we categorized each study into one of three types (histology, gross anatomy, or surgical training) based on our interpretation of the primary use of the tissue by each the investigators. Note that "histology" as the primary goal for a study is defined to include neuropathologic examination, forensic examination, or to study biomolecular and morphologic mechanisms of human brain function and disease. NR: Not reported

fixation while the brain was still in the skull (i.e., in situ perfusion) or whether they removed the brain from the skull prior to performing the perfusion fixation (i.e., ex situ perfusion). There were two major subcategories for each approach. For the in situ approach, vessels were accessed either after making surgical incisions in the neck (or thorax) or after separating the head. For the ex situ approach, vessels were accessed either in the whole brain or in one isolated brain hemisphere. Two studies reported on multiple approaches. Istomin [43] reported methods for both ex situ whole brain and in situ neck dissection approaches, whereas Waldvogel et al. [96] reported methods for both ex situ whole brain and ex situ one-hemisphere approaches.

For the in situ approaches, one of the challenges described was difficulty perfusing the brain in the context of 


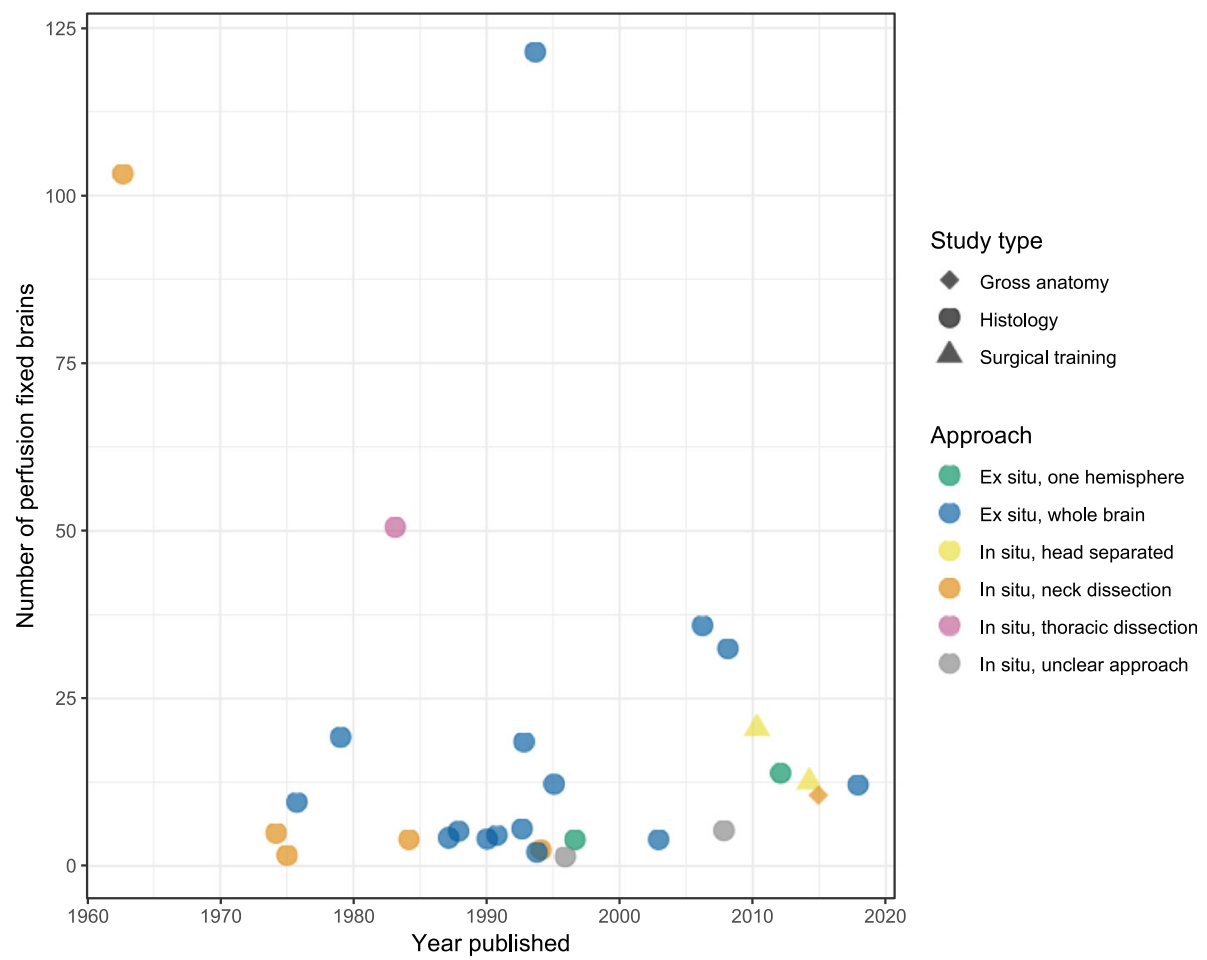

Fig. 2 Characteristics of human brain perfusion fixation methods employed over time. Studies that had unclear approaches or did not report the number of perfusion-fixed brains are not drawn in the figure. This chart was prepared using R (v. 3.5.1) and the ggplot2 package

brain circulation deficits and/or brain trauma. Kalimo et al. [45] reported that in two of the five brains that they attempted to fix via perfusion, there was no fixation noted when the brain was removed; in both of these cases, there was evidence to suggest premortem deficits in circulation to the brain. Böhm [12], who performed the procedure on cadavers that had suffered injury to the head and brain, reported that the increased intracranial pressure resulting from brain death prevented cerebral perfusion throughout the internal carotid distribution. This was indicated by postmortem angiography that stopped at the intracranial internal carotid artery, which they called the "no-reflow phenomenon." To mitigate this problem, Böhm [12] opened the skull and capped the upper half of the brain prior to perfusion fixation. This problem appears to be mitigated by using the ex situ approach. For example, Sharma et al. [79], who used the ex situ approach, reported perfusion fixation on brains donated from 5 individuals who had raised intracranial tension, or "pump brain," prior to death. They found adequate or high-quality histology results when they did perfusion fixation on these brain samples.

Another challenge with the in situ approach is that it is more difficult to monitor perfusion fixation. Because the brain should harden during fixation, in an ex situ approach, it is possible to directly monitor fixation by applying pressure to the brain and noting resistance. In the in situ approach, the best monitoring method is likely fixation of the eyeball, which Donckaster et al. [24] and Latini et al. [53] both reported to be a suitable proxy for intracranial fixation. However, fixation of the eye may not always be completely reliable, due in part to the anastomosis between the external carotid and internal carotid through the ophthalmic artery. Kalimo et al. [45] reported that even after clamping the external carotid artery, partial fixation of tissues in the external carotid distribution would occur unless digital pressure was applied to the inner supraciliary skin and perfusion fixation was kept to a short period of time. Finally, a practical downside of the in situ approach is that it can interfere with funeral and embalming practices. For example, Istomin [43] noted that it was necessary to prepare the face of the cadaver prior to beginning the perfusion fixation, such as closing the eyes.

The in situ separated head approach was reported by 3 studies, all of which had the primary goal of surgical training. One consideration for the in situ separated head approach is the spinal level at which the head separation should be performed. Benet et al. [9] performed the separation at vertebral levels $\mathrm{C} 5-\mathrm{C} 7$ to allow for sufficient exposure of the cervical vessels, while retaining the cervical spinal cord.

For the ex situ approaches, one of the challenges described is the mechanical damage and deformation that 
occurs while the organ is removed from its regular location in the skull. In the animal literature, mechanical postmortem trauma has been found to result in histological artifacts such as dark neurons [44]. Investigators described several different approaches to minimize trauma. One approach is to suspend the brain in cloth; for example, Istomin [43] reported using a hammock of dense fabric for holding the brain in place. Another approach is to bathe the brain in liquid; for example, Beach et al. [7] placed the brain in phosphate-buffered saline. Beach et al. [7] reported that of these two methods, the liquid bath solution may lead to less mechanical damage. Another challenge with the ex situ approach is that the arteries can be easily damaged while handling the brain, which will make subsequent perfusion more challenging or impossible. Beach et al. [7] reported that when they removed the brain, they severed the carotid arteries so that there would still be long segments attached to the circle of Willis.

Regarding the ex situ one hemisphere approach, there are some special considerations. The process of cutting the brain introduces additional mechanical trauma that causes damage to the unfixed brain tissue and severs the arteries that supply the contralateral hemisphere, requiring additional artery ligations to prevent leakage of washout and fixative solution. Furthermore, the absence of collateral circulation from the contralateral circulation is likely to lead to worse overall fixation quality compared to the whole brain approach. In the process of cutting one hemisphere, it is also necessary to cut off the brainstem and cerebellum, with the result that these brain regions will not be perfusion-fixed because they are detached from the rest of the brain where the fixative is being perfused [95]. As a result of these problems, the ex situ one hemisphere approach is typically performed only in cases where the other hemisphere needs to remain unfixed, to preserve the tissue for biomolecular or biochemical studies.

Taken together, there were four major approaches to brain perfusion fixation reported, each of which have reported benefits and downsides, although there is very little data on comparisons among them.

\section{Brain donor exclusion criteria for perfusion}

Many of the studies listed criteria for the inclusion of brain tissue in their studies; however, it was almost always unclear whether these exclusion criteria were specific to the perfusion fixation preservation procedure rather than overall inclusion in the study. The one exception is Adickes et al. (1996) [2], in which cerebral vessel thrombosis or large intracerebral hemorrhages were both exclusion criteria specifically for perfusion fixation. In these cases, the investigators used immersion fixation. These exclusion criteria make biological sense, as these conditions are likely to interfere with flow through the cerebrovascular tree and therefore prevent adequate fixation.

While we did not identify any study that specifically noted that an extended postmortem interval (PMI) was an exclusion criterion for perfusion fixation, many of the studies reported the PMI range of the brain tissue used in their studies. The PMI range tolerated appeared to be associated with the goals of the investigators. On one extreme, Latini et al. [53], who studied gross anatomy of the white matter, reported that they tolerated a PMI of up to 7 days, which was the longest PMI range we identified among the included studies. At the other extreme, Kalimo et al. [45], who studied ultrastructure of brain parenchyma, used an "immediate autopsy" method such that their perfusion fixation procedure began within two minutes of death and the entire procedure was done within approximately 20 to $30 \mathrm{~min}$ after death. Another study of ultrastructure, by Suzuki et al. [86], also required brain donors with a relatively short PMI of less than $5 \mathrm{~h}$. They noted that autopsy cases after $5 \mathrm{~h}$ demonstrated worse preservation of the cytoplasm or cellular organelles, including vacuolar and liquefaction changes, which they attributed to autolysis. Somewhere in the middle of these extremes fell the majority of the light microscopy-based immunohistochemistry studies. For example, Beach et al. [7] reported that they achieved "satisfactory" staining with PMIs of up to $18 \mathrm{~h}$, although they noted that their immunohistochemistry results were best with brain tissue less than $12 \mathrm{~h}$ postmortem. As another immunohistochemistry example, Halliday et al. [35] performed perfusion fixation on brains with PMIs of up to $35 \mathrm{~h}$.

In summary, cerebral vessel thrombosis or large intracerebral hemorrhages were the only exclusion criteria specific to perfusion fixation. Several studies also suggested that a short PMI was preferred, with the PMI range tolerated depending on the type of the downstream study.

\section{Vessels accessed for perfusion}

Among the studies that we evaluated, there were many different choices in the vessels that they accessed for subsequent perfusion steps, which depended on the overall approach that they employed (Table 2). A key trade-off is ease of vascular access and technical perfusion quality versus the degree of dependence on intact collateral circulation for reaching more distant brain regions.

All of the included studies attempted to perfuse the anterior circulation of the brain via the carotid artery distribution in some form; either via the common carotid artery or arteries, internal carotid artery or arteries, or the aortic arch. Waldvogel et al. [96] also reported 
Table 2 Vascular access strategies reported by the included studies

\begin{tabular}{|c|c|c|c|c|}
\hline Study & Approach & Vessels Accessed & Cannula & Vessels Occluded \\
\hline Adickes 1996 [2] & $\begin{array}{l}\text { Ex situ, both } \\
\text { hemispheres }\end{array}$ & $\begin{array}{l}\text { Unilateral vertebral artery, bilateral } \\
\text { carotid arteries }\end{array}$ & 18G cannula & Contralateral vertebral artery \\
\hline Adickes 1997 [1] & $\begin{array}{l}\text { Ex situ, one } \\
\text { hemisphere }\end{array}$ & $\begin{array}{l}\text { Internal carotid artery; if the PCOA } \\
\text { was too small or not present, } \\
\text { second cannula placed in the } \\
\text { posterior cerebral artery }\end{array}$ & 18G plastic cannula & $\begin{array}{l}\text { Basilar and contralateral } \\
\text { cerebral arteries }\end{array}$ \\
\hline Alvernia 2010 [3] & In situ, head separated & $\begin{array}{l}\text { Common carotid arteries, } \\
\text { vertebral arteries, } \\
\text { internal jugular veins }\end{array}$ & $\begin{array}{l}\text { One-way urinary catheter } \\
\text { (largest possible) }\end{array}$ & NR \\
\hline $\begin{array}{l}\text { Beach } 1987 \\
\text { [7] }\end{array}$ & Ex situ, whole brain & $\begin{array}{l}\text { Bilateral internal carotid arteries, } \\
\text { bilateral vertebral arteries } \\
\text { or basilar artery }\end{array}$ & Plastic IV cannula & NR \\
\hline $\begin{array}{l}\text { Benet } 2014 \\
\text { [9] }\end{array}$ & In situ, head separated & $\begin{array}{l}\text { Common carotid arteries, } \\
\text { vertebral arteries, } \\
\text { jugular veins }\end{array}$ & NR & NR \\
\hline $\begin{array}{l}\text { Böhm } 1983 \\
{[12]}\end{array}$ & $\begin{array}{l}\text { In situ, thoracic } \\
\text { dissection }\end{array}$ & Aortic arch & Wide balloon catheter & NR \\
\hline Coveñas 2003 [20] & Ex situ, whole brain & Carotid and vertebral arteries & NR & NR \\
\hline $\begin{array}{l}\text { de Oliveira } 2012 \\
\text { [23] }\end{array}$ & $\begin{array}{l}\text { Ex situ, one } \\
\text { hemisphere }\end{array}$ & $\begin{array}{l}\text { Internal carotid artery, posterior } \\
\text { communicating artery* }\end{array}$ & $20 \mathrm{G}$ peripheral catheter* & $\begin{array}{l}\text { Basilar artery* and } \\
\text { contralateral hemisphere } \\
\text { arteries }\end{array}$ \\
\hline $\begin{array}{l}\text { Donckaster } 1963 \\
\text { [24] }\end{array}$ & In situ, neck dissection & $\begin{array}{l}\text { Bilateral carotids, with or without } \\
\text { vertebral arteries }\end{array}$ & Irrigation cannula & External carotids \\
\hline Feekes 2005 [28] & Unclear & Carotid artery & NR & NR \\
\hline Grinberg 2008 [34] & Ex situ, whole brain & $\begin{array}{l}\text { Bilateral internal carotid arteries and } \\
\text { vertebral arteries* }\end{array}$ & Olive $C$ cannula* & NR \\
\hline Halliday 1988 [35] & Ex situ, whole brain & Carotid and vertebral arteries & NR & NR \\
\hline $\begin{array}{l}\text { Huang } 1993 \\
\text { [40] }\end{array}$ & Ex situ, whole brain & $\begin{array}{l}\text { Bilateral internal carotid arteries and } \\
\text { vertebral arteries }\end{array}$ & NR & NR \\
\hline Insausti 1995 [42] & Ex situ, whole brain & $\begin{array}{l}\text { Both internal carotids, if both PCoAs } \\
\text { were sufficient diameter; One carotid } \\
\text { and the basilar artery otherwise }\end{array}$ & NR & $\begin{array}{l}\text { Non-cannulated arteries } \\
\text { were ligated }\end{array}$ \\
\hline Istomin 1994 [43] & Ex situ, whole brain & $\begin{array}{l}\text { Internal carotid arteries and basilar } \\
\text { arteries }\end{array}$ & NR & NR \\
\hline Istomin 1994 [43] & In situ, neck dissection & Bilateral carotid arteries & NR & NR \\
\hline Kalimo 1974 [45] & In situ, neck dissection & $\begin{array}{l}\text { Initial segment of the right internal } \\
\text { carotid artery }\end{array}$ & Glass cannula & $\begin{array}{l}\text { Right external carotid, } \\
\text { both left carotid arteries, } \\
\text { and vertebral arteries }\end{array}$ \\
\hline Latini 2015 [53] & In situ, neck dissection & Left or right common carotid artery & NR & NR \\
\hline Lyck 2008 [58] & $\begin{array}{l}\text { In situ, unclear } \\
\text { approach }\end{array}$ & Internal carotid artery & NR & NR \\
\hline Masawa 1993 [59] & Ex situ, whole brain & Bilateral internal carotid arteries & NR & NR \\
\hline Masawa 1994 [60] & Ex situ, whole brain & Bilateral carotid arteries & $N R$ & NR \\
\hline McKenzie 1994 [64] & In situ, neck dissection & Bilateral common carotid arteries & $\begin{array}{l}\text { Polyethylene cannula } \\
\text { (1/4" outside diameter) }\end{array}$ & $\begin{array}{l}\text { Vertebral arteries and } \\
\text { internal jugular veins } \\
\text { (intermittently clamped) }\end{array}$ \\
\hline Nakamura 1991 [69] & Ex situ, whole brain & $\begin{array}{l}\text { Bilateral internal carotid and } \\
\text { vertebral arteries }\end{array}$ & NR & NR \\
\hline $\begin{array}{l}\text { Pakkenberg } 1966 \\
\text { [70] }\end{array}$ & $\begin{array}{l}\text { In situ, unclear } \\
\text { approach }\end{array}$ & Unilateral carotid artery & NR & NR \\
\hline Sharma 2006 [79] & Ex situ, whole brain & $\begin{array}{l}\text { Blood vessels at the base of the } \\
\text { brain and floor of the third } \\
\text { ventricle (non-vessel) }\end{array}$ & NR & NR \\
\hline Shinkai 1976 & Ex situ, whole brain & Bilateral internal carotid and vertebral & NR & NR \\
\hline
\end{tabular}


Table 2 Vascular access strategies reported by the included studies (Continued)

\begin{tabular}{|c|c|c|c|c|}
\hline Study & Approach & Vessels Accessed & Cannula & Vessels Occluded \\
\hline$\overline{[81]}$ & & arteries & & \\
\hline $\begin{array}{l}\text { Sutoo } 1994 \\
\text { [85] }\end{array}$ & Ex situ, whole brain & $\begin{array}{l}\text { Bilateral internal carotid arteries } \\
\text { and basilar artery }\end{array}$ & NR & $N R$ \\
\hline $\begin{array}{l}\text { Suzuki } 1979 \\
{[86]}\end{array}$ & Ex situ, whole brain & Bilateral middle cerebral arteries & NR & NR \\
\hline $\begin{array}{l}\text { Tanaka } 1975 \\
\text { [87] }\end{array}$ & In situ, neck dissection & Left internal carotid artery & NR & NR \\
\hline $\begin{array}{l}\text { Torack } 1990 \\
\text { [90] }\end{array}$ & Ex situ, whole brain & $\begin{array}{l}\text { Bilateral internal carotid arteries } \\
\text { and the basilar artery }\end{array}$ & NR & $\begin{array}{l}\text { After initial perfusion fixation, } \\
\text { clamped vessels to isolate the } \\
\text { hippocampus }\end{array}$ \\
\hline Turkoglu 2014 [92] & In situ, head separated & Bilateral internal carotid arteries & $\begin{array}{l}\text { One-way number } \\
10 \text { Foley urinary } \\
\text { catheters }\end{array}$ & External carotid arteries \\
\hline $\begin{array}{l}\text { von Keyserlingk } 1984 \\
\text { [93] }\end{array}$ & In situ, neck dissection & $\begin{array}{l}\text { Internal carotid artery, } \\
\text { vertebral artery }\end{array}$ & NR & NR \\
\hline Waldvogel 2006 [96] & Ex situ, whole brain & Basilar and internal carotid arteries & $\begin{array}{l}21 \mathrm{G} \text { winged infusion } \\
\text { needles }\end{array}$ & Leaking vessels occluded \\
\hline Waldvogel 2006 [96] & $\begin{array}{l}\text { Ex situ, one } \\
\text { hemisphere }\end{array}$ & $\begin{array}{l}\text { Internal carotid, vertebral, } \\
\text { and anterior cerebral arteries }\end{array}$ & $\begin{array}{l}21 \mathrm{G} \text { winged infusion } \\
\text { needles }\end{array}$ & Leaking vessels occluded \\
\hline $\begin{array}{l}\text { Welikovitch } 2018 \\
\text { [99] }\end{array}$ & Ex situ, whole brain & $\begin{array}{l}\text { Internal carotid and vertebral } \\
\text { arteries }\end{array}$ & Serum 1 needle* & $N R$ \\
\hline
\end{tabular}

cannulation of the anterior cerebral artery in their ex situ one hemisphere approach. If only one side of the two carotid arteries is cannulated for perfusion, then interhemispheric collateral circulation will likely provide some fixative to the other hemisphere via the anterior communicating artery [55]. However, the perfusion quality in that hemisphere will be limited, especially if the anterior communicating artery is absent or hypoplastic [78]. In the in situ approach, if the internal carotid was cannulated, several of the investigators (Table 2) also clamped the external carotid to prevent shunting of perfusate to the often lower-pressure external carotid circulatory distribution, as opposed to the brain.

Slightly more than half $(20 / 32$ or $62.5 \%)$ of the included studies reported consistently cannulating vessels in the posterior circulation in some form; either the vertebral artery or arteries, basilar artery, posterior cerebral artery, or the aortic arch. The remainder of the studies either did not focus on brain regions supplied by the posterior circulation or relied on collateral circulation from the anterior to the posterior circulatory system. Collateral circulation via the posterior communication arteries is not intact in approximately one-fifth of people [102], although some degree of leptomeningeal collateral circulation may still be present [73]. Notably, the ability to visualize the posterior communicating arteries directly is an advantage of the ex situ approach, as the likely amount of collateral circulation through the circle of Willis can be visually assessed and the vessels to perfuse chosen accordingly (performed by Insausti et al. [42] and Adickes et al. (1997) [1]).

For obvious reasons, it is technically easier to cannulate fewer arteries, and this also decreases the time interval for tissue degradation prior to the initiation of washout and fixation. Cannulating more arteries also potentially affects perfusion quality within each one of the arteries when using a perfusion setup with a tube splitter to distribute the perfusate, as was used in Beach et al. [7]. This is because perfusion flow will distribute to the lowest pressure arteries, and cannulating a low-pressure artery that distributes fixative to a less important region of the brain may lead to worse quality fixation in a more important region of the brain. Finally, one of the advantages of the ex situ approach is that it is easier to access more blood vessels on the ventral surface of the brain without requiring more extensive neck dissection to access the vertebral artery. Relatively more of the studies using the ex situ than the in situ neck dissection approach reported consistently cannulating at least one artery in the posterior circulatory system (Table 2).

One study, Sharma et al. [79], reported perfusion fixation via the lateral ventricles using the ex situ approach, in addition to the blood vessels. This method likely allowed for improved fixation of periventricular brain structures such as the hypothalamus. The lateral ventricular perfusion method was also used with good reported results by Toga et al., who used an in situ approach and was not identified by our formal search 
methods [89]. This study found that their intraventricular delivery system led to better and more uniform fixation preservation quality than perfusion of fixatives through the carotid and vertebral arteries. They speculated that this was due to erratic blood clot formation during the postmortem interval.

Torack et al. [90] reported a unique procedure in an attempt to isolate the hippocampus as a target for perfusion fixation. They first perfused through the internal carotid arteries and the basilar artery. Next, they clamped the middle cerebral artery distal to the anterior choroidal artery and the posterior cerebral artery distal to the posterior choroidal arteries. Following these occlusions, the perfusion fixation should have been more targeted to the hippocampus.

The main goal of vascular access points in perfusion fixation is to perfuse a large portion of the brain with little damage to the tissue. The studies that were able to successfully cannulate the anterior circulation as well as the posterior circulation would likely perfuse the largest amount of brain tissue. We are unable to determine if the quality of the tissue isolated from brains with different perfusion access protocols is significantly different.

\section{Washout solution used}

Slightly more than half (20/35 or $57 \%$ ) of the included studies reported using a washout solution prior to perfusion fixation (Table 3). This step aims to remove clots, blood cells, and other intravascular debris to improve flow of fixative, although it comes at the cost of increased procedural complexity and a longer delay prior to fixation. Adickes et al. (1997) [1] did not use a "pre-perfusion" or washout step with saline because it would make the procedure more burdensome on staff. Donckaster et al. [24] only used their washout solution in cases with a PMI of more than $12 \mathrm{~h}$ prior to the initiation of the procedure, with the goal of preventing the fixation of blood clots. Of the studies that employed a washout step, saline or phosphate-buffered saline were the most common base washout solutions used, while two of the studies used mannitol, and one study used Ringer solution.

Published perfusion fixation methods for laboratory animals often start while the animal is anesthetized [30]. This protocol prevents substantial premortem and postmortem clot formation [36], which means that the major purpose of the washout solution is to remove blood cells from the vessels. On the other hand, in postmortem human brain perfusion fixation, there is frequently an abundance of blood clots that limit perfusion quality [22]. This means that in addition to washing out the cells, the washout step is often used by investigators to also decrease the clot burden by driving them out with pressure. Böhm [12] noted that the washout step removed most clots that had formed postmortem, while clots that were formed premortem could only be washed out if a higher perfusion pressure was employed. Notably, the goal of Böhm [12] was to preserve premortem clots for forensic purposes, whereas studies using perfusion fixation to study brain parenchyma typically aimed to remove clots in order to improve perfusate flow and resulting fixation quality.

In addition to mechanically removing blood clots via perfusion pressure, another approach is to degrade or inhibit clots enzymatically. Four of the studies added the anticoagulant heparin to their washout solution, which may help to limit the spread of blood clots (Table 3). One of the studies, Böhm [12], reported the occasional use of dextran 40, which also has antithrombotic properties [74].

Two of the studies, Halliday et al. [35] and Waldvogel et al. [96], reported the addition of sodium nitrite to the washout solution. Sodium nitrite may help to dilate blood vessels and has been found to improve perfusion fixation quality in animals [71].

The volume of the washout solution varied considerably, from as little as $180 \mathrm{ml}$ to as much as 51 . Several of the studies also reported performing the washout step until the venous outflow was clear of blood, clots, or debris.

One potential problem with the use of a washout solution in brain perfusion fixation is that it may induce brain edema. In animal studies it has been shown that perfusing too much saline into the brain (e.g., one liter) can cause edema [11]. The edema induced may be related to the osmotic concentration of the washout solution. Consistent with this, Benet et al. [9] found that washing out with an isotonic saline solution rather than tap water led to decreased tissue edema. Grinberg et al. [34] compared a hyperosmolar solution of $20 \%$ mannitol with a solution of $0.9 \% \mathrm{NaCl}$, finding that $20 \%$ mannitol led to substantially less brain swelling. Böhm [12] also used a hyperosmolar washout solution (680 mOsm) composed of Ringer solution in $0.2 \mathrm{M}$ phosphate buffer.

Overall, the majority of articles included a washout step, most commonly using $1-51$ of saline as the base washout solution. The additives used and the precise procedure reported differed widely, and there were few comparisons between methods.

\section{Fixative solution used}

Consistent with its widespread use throughout pathology and histology, formaldehyde was a component of the fixative used in almost all studies. The only exceptions were one condition in Grinberg et al. [34] that employed 70\% ethanol only (which did not lead to successful fixation) and 3 studies that used glutaraldehyde only (Table 4). Some studies used paraformaldehyde, which is a polymerized 
Table 3 Washout solutions used by the included studies

\begin{tabular}{|c|c|c|c|c|c|c|c|c|}
\hline Study & Base solution & Additives & $\begin{array}{l}\text { Drive } \\
\text { method }\end{array}$ & Time & Amount & Rate & Pressure & Stopping criterion \\
\hline $\begin{array}{l}\text { Alvernia } \\
2010[3]\end{array}$ & Warm tap water & NR & $\begin{array}{l}\text { Syringe } \\
(60 \mathrm{ml})\end{array}$ & $N R$ & $2-41$ & NR & NR & $\begin{array}{l}\text { Until water flow was clear } \\
\text { (clot/debris removal) }\end{array}$ \\
\hline $\begin{array}{l}\text { Beach } \\
1987[7]\end{array}$ & Ice cold PBS & NR & Pump & $\begin{array}{l}10- \\
20 \min \end{array}$ & 11 & $\begin{array}{l}50-100 \\
\mathrm{ml} / \mathrm{min}\end{array}$ & NR & NR \\
\hline $\begin{array}{l}\text { Benet } \\
2014[9]\end{array}$ & Isotonic saline & NR & NR & $N R$ & $N R$ & NR & "Low pressure" & $\begin{array}{l}\text { Until contralateral } \\
\text { outflow was clear }\end{array}$ \\
\hline $\begin{array}{l}\text { Böhm } \\
1983 \text { [12] }\end{array}$ & $\begin{array}{l}\text { Ringer solution in } \\
0.2 \mathrm{M} \text { phosphate } \\
\text { buffer ( } \mathrm{pH} 7.5 \text { ) }\end{array}$ & $\begin{array}{l}\text { Rheomacrodex } \\
\text { (Dextran 40) }\end{array}$ & Gravity & $\begin{array}{l}5- \\
10 \min \end{array}$ & 51 & $\begin{array}{l}500- \\
1000 \mathrm{ml} / \\
\min \end{array}$ & NR & $\begin{array}{l}\text { Until blood and blood } \\
\text { clots were washed away }\end{array}$ \\
\hline $\begin{array}{l}\text { Coveñas } \\
2003 \text { [20] }\end{array}$ & $\begin{array}{l}0.15 \mathrm{M} \mathrm{PBS} \\
(\mathrm{pH} 7.2)\end{array}$ & NR & Pump & $N R$ & 11 & NR & NR & NR \\
\hline $\begin{array}{l}\text { de Oliveira } \\
2012 \text { [23] }\end{array}$ & Mannitol & Warm heparin & Gravity & $N R$ & $250 \mathrm{ml}$ & NR & NR & NR \\
\hline $\begin{array}{l}\text { Donckaster } \\
1963[24]\end{array}$ & $\begin{array}{l}\text { Physiological } \\
\text { saline }\end{array}$ & NR & NR & $N R$ & NR & NR & NR & NR \\
\hline $\begin{array}{l}\text { Grinberg } \\
2008[34]\end{array}$ & $\mathrm{NaCl} 0.9 \%$ & NR & Gravity* & NR & NR & NR & $\begin{array}{l}147.4 \mathrm{mmHg} \\
\text { (height of } 2 \mathrm{~m}^{*} \text { ) }\end{array}$ & NR \\
\hline $\begin{array}{l}\text { Grinberg } \\
2008[34]\end{array}$ & 20\% Mannitol & Heparin & Gravity* & NR & $250 \mathrm{ml}$ & NR & $147.4 \mathrm{mmHg}$ & NR \\
\hline $\begin{array}{l}\text { Halliday } \\
1988[35]\end{array}$ & $\begin{array}{l}0.1 \text { M Sodium } \\
\text { phoshate } \\
\text { (pH 7.4) }\end{array}$ & $\begin{array}{l}1 \% \text { sodium } \\
\text { nitrite }\end{array}$ & Pump & $N R$ & 51 & NR & $\begin{array}{l}\text { "Normal mean } \\
\text { arterial pressure" }\end{array}$ & NR \\
\hline $\begin{array}{l}\text { Huang } \\
1993[40]\end{array}$ & PBS & NR & NR & $\begin{array}{l}33 \\
\operatorname{mins}\end{array}$ & 41 & $\begin{array}{l}120 \mathrm{ml} / \\
\mathrm{min}\end{array}$ & $N R$ & NR \\
\hline $\begin{array}{l}\text { Insausti } \\
1995 \text { [42] }\end{array}$ & Saline at $4^{\circ} \mathrm{C}$ & $\begin{array}{l}\text { Heparin, 10,000 } \\
\text { units }\end{array}$ & NR & $\begin{array}{l}20 \\
\operatorname{mins}\end{array}$ & 21 & $\begin{array}{l}100 \mathrm{ml} / \\
\mathrm{min}\end{array}$ & $N R$ & $N R$ \\
\hline $\begin{array}{l}\text { Istomin } \\
1994[43]\end{array}$ & Saline & NR & $\begin{array}{l}\text { Gravity or } \\
\text { Syringe }\end{array}$ & NR & NR & NR & $150 \mathrm{mmHg}$ & $\begin{array}{l}\text { Clear fluid flow from the } \\
\text { veins }\end{array}$ \\
\hline $\begin{array}{l}\text { Kalimo } \\
1974[45]\end{array}$ & $\mathrm{NaCl} 0.9 \%$ & $N R$ & Gravity & $\begin{array}{l}<=5 \\
\operatorname{mins}\end{array}$ & NR & $N R$ & NR & NR \\
\hline $\begin{array}{l}\operatorname{Lin} \\
2000[57]\end{array}$ & $\begin{array}{l}0.01 \mathrm{M} \mathrm{PBS} \\
(\mathrm{pH} 7.4)\end{array}$ & $N R$ & NR & NR & NR & NR & NR & $N R$ \\
\hline $\begin{array}{l}\text { Nakamura } \\
1991 \text { [69] }\end{array}$ & $\begin{array}{l}0.01 \text { M sodium- } \\
\text { PBS ( } \mathrm{pH} 7.4)\end{array}$ & NR & Pump & NR & 11 & NR & $N R$ & $N R$ \\
\hline $\begin{array}{l}\text { Sutoo } \\
1994[85]\end{array}$ & $\begin{array}{l}\text { Ice cold PBS } \\
(\mathrm{pH} 7.4)\end{array}$ & NR & NR & $N R$ & 21 & NR & NR & $N R$ \\
\hline $\begin{array}{l}\text { Torack } \\
1990[90]\end{array}$ & PBS & $N R$ & NR & NR & $\begin{array}{l}180 \mathrm{ml}(60 \mathrm{ml} \text { in } \\
\text { each vessel) }\end{array}$ & NR & $N R$ & $N R$ \\
\hline $\begin{array}{l}\text { Turkoglu } \\
2014[92]\end{array}$ & Saline & NR & Gravity & NR & 31 & NR & $\begin{array}{l}110 \mathrm{mmHg} \\
\text { (height of } 1.5 \mathrm{~m} \text { ) }\end{array}$ & $\begin{array}{l}\text { Until no visible blood or } \\
\text { clots drained from the IJVs }\end{array}$ \\
\hline $\begin{array}{l}\text { Waldvogel } \\
2006[96]\end{array}$ & PBS (pH 7.4) & $\begin{array}{l}1 \% \text { sodium } \\
\text { nitrite }\end{array}$ & Pump & $\begin{array}{l}15 \\
\operatorname{mins}\end{array}$ & 0.51 & $\begin{array}{l}\sim 33 \mathrm{ml} / \\
\min \end{array}$ & $N R$ & $\begin{array}{l}15 \text { min or until the brain is } \\
\text { cleared of blood }\end{array}$ \\
\hline $\begin{array}{l}\text { Welikovitch } \\
2018 \text { [99] }\end{array}$ & $\begin{array}{l}\text { Physiological } \\
\text { saline }\end{array}$ & $0.33 \%$ heparin & Gravity & $\begin{array}{l}30 \\
\text { mins }\end{array}$ & 1.51 & $\begin{array}{l}50 \mathrm{ml} / \\
\min \end{array}$ & $N R$ & $N R$ \\
\hline
\end{tabular}

If the study is not listed here, then it did not report the use of a washout solution. If gravity was used to drive perfusate, we used the formula $\mathrm{P}=\rho \mathrm{gh}$, where $\mathrm{P}=$ hydrostatic pressure, $\rho=$ density of substance (assumed equal to water), $g=$ gravitational acceleration, and $h=h e i g h t$, to calculate the pressure. Asterisks indicate personal communications. NR: Not reported, PBS: Phosphate-buffered saline, IJV: Internal jugular vein

storage form of formaldehyde, while others used formalin, which is a form of formaldehyde that includes methanol to inhibit polymerization. $10 \%$ formalin is composed of $3.7 \%$ formaldehyde with around $1 \%$ or less of methanol [88]. Paraformaldehyde typically requires depolymerization via heating and/or sodium hydroxide prior to use, thus adding another setup step that adds complexity and will potentially prolong the interval prior to the initiation of the procedure [47]. The addition of methanol in formalin keeps the formaldehyde depolymerized and avoids its precipitation.

Twelve of the studies employed glutaraldehyde in the perfusion solution, at various concentrations ranging 
Table 4 Fixative solutions reported by the included studies

\begin{tabular}{|c|c|c|c|c|c|c|c|}
\hline Study & Fixative solution & Buffer & Drive & Time & Amount & $\begin{array}{l}\text { Flow } \\
\text { rate }\end{array}$ & Pressure \\
\hline $\begin{array}{l}\text { Adickes } 1996 \\
\text { [2] }\end{array}$ & $10 \%$ buffered formalin & NR & Gravity & $\begin{array}{l}15- \\
20 \mathrm{~min}\end{array}$ & 21 & $\begin{array}{l}100- \\
133 \mathrm{ml} / \\
\mathrm{min}\end{array}$ & $\begin{array}{l}75.6 \mathrm{mmHg} \\
\text { (height of } 1 \mathrm{~m} \text { ) }\end{array}$ \\
\hline $\begin{array}{l}\text { Adickes } 1997 \\
\text { [1] }\end{array}$ & $10 \%$ buffered formalin & Phosphate & Gravity & $\begin{array}{l}15- \\
20 \text { min }\end{array}$ & 21 & $\begin{array}{l}100- \\
133 \mathrm{ml} / \\
\min \end{array}$ & $\begin{array}{l}75.6 \mathrm{mmHg} \\
\text { (height of } 1 \mathrm{~m} \text { ) }\end{array}$ \\
\hline $\begin{array}{l}\text { Alvernia } \\
2010[3]\end{array}$ & $\begin{array}{l}\text { Formaldehyde } 37 \% \text { and ethyl } \\
\text { alcohol } 10 \%\end{array}$ & NR & $\begin{array}{l}\text { Syringe } \\
(60 \mathrm{ml})\end{array}$ & NR & NR & NR & NR \\
\hline $\begin{array}{l}\text { Beach } \\
1987[7]\end{array}$ & $\begin{array}{l}4 \% \text { paraformaldehyde } \\
\text { (ice cold) }\end{array}$ & $\begin{array}{l}0.1 \mathrm{M} \text { phosphate } \\
\text { buffer ( } \mathrm{pH} 7.4)\end{array}$ & Pump & $\begin{array}{l}40- \\
80 \text { min }\end{array}$ & 41 & $\begin{array}{l}50-100 \\
\mathrm{ml} / \mathrm{min}\end{array}$ & NR \\
\hline $\begin{array}{l}\text { Benet } \\
2014[9]\end{array}$ & $10 \%$ formaldehyde & NR & NR & NR & 0.71 & NR & NR \\
\hline $\begin{array}{l}\text { Benet } \\
2014[9]\end{array}$ & $\begin{array}{l}\text { Custom solution: ethanol } \\
62.4 \% \text {, glycerol } 17 \% \text {, } \\
\text { phenol } 10.2 \% \text {, formaldehyde } \\
2.3 \% \text {, and water } 8.1 \%\end{array}$ & NR & NR & NR & 0.71 & NR & NR \\
\hline $\begin{array}{l}\text { Böhm } \\
1983 \text { [12] }\end{array}$ & $2 \%$ glutaraldehyde & $\begin{array}{l}0.2 \mathrm{M} \text { phosphate } \\
\text { buffer }\end{array}$ & Gravity & $\begin{array}{l}5- \\
10 \min \end{array}$ & $5-101$ & $\begin{array}{l}\sim 1000 \\
\mathrm{ml} / \mathrm{min}\end{array}$ & $\begin{array}{l}25.7-47.8 \\
\mathrm{mmHg}\end{array}$ \\
\hline $\begin{array}{l}\text { Coveñas } \\
2003[20]\end{array}$ & $4 \%$ paraformaldehyde & $\begin{array}{l}0.15 \mathrm{M} \mathrm{PBS} \\
(\mathrm{pH} 7.2)\end{array}$ & NR & NR & 31 & NR & $\begin{array}{l}\text { "Normal mean } \\
\text { arterial pressure" }\end{array}$ \\
\hline $\begin{array}{l}\text { de Oliveira } \\
2012 \text { [23] }\end{array}$ & $20 \%$ formalin & NR & Gravity & NR & $5 \mathrm{LI}$ & NR & NR \\
\hline $\begin{array}{l}\text { Donckaster } \\
1963[24]\end{array}$ & $\begin{array}{l}\text { Cajal fixative: formalin and } \\
\text { ammonium bromide }\end{array}$ & NR & NR & NR & $\begin{array}{l}900 \mathrm{ml} \\
(300 \mathrm{ml} \text { in children } \\
<12 \text { years old })\end{array}$ & NR & $<200 \mathrm{mmHg}$ \\
\hline $\begin{array}{l}\text { Feekes } \\
2005 \text { [28] }\end{array}$ & $10 \%$ formalin & NR & NR & NR & NR & NR & NR \\
\hline $\begin{array}{l}\text { Feekes } \\
2005 \text { [28] }\end{array}$ & $\begin{array}{l}2.5 \% \text { formaldehyde, } \\
6 \% \text { isopropyl alcohol, } \\
1 \% \text { glycerin }\end{array}$ & NR & NR & NR & NR & NR & NR \\
\hline $\begin{array}{l}\text { Grinberg } \\
2008[34]\end{array}$ & $10 \%$ formalin & None & Gravity & NR & 51 & NR & $\begin{array}{l}147.4 \mathrm{mmHg} \\
\text { (height of } 2 \mathrm{~m}^{*} \text { ) }\end{array}$ \\
\hline $\begin{array}{l}\text { Grinberg } \\
2008[34]\end{array}$ & $20 \%$ formalin & None & Gravity & NR & 51 & NR & $147.4 \mathrm{mmHg}$ \\
\hline $\begin{array}{l}\text { Grinberg } \\
2008[34]\end{array}$ & $70 \%$ ethanol & None & Gravity & NR & 51 & NR & $147.4 \mathrm{mmHg}$ \\
\hline $\begin{array}{l}\text { Grinberg } \\
2008[34]\end{array}$ & Acetic acid-alcohol-formalin & None & Gravity & NR & 51 & NR & $147.4 \mathrm{mmHg}$ \\
\hline $\begin{array}{l}\text { Halliday } 1988 \\
\text { [35] }\end{array}$ & $\begin{array}{l}4 \% \text { formaldehyde, } \\
2 \% \text { picric acid; followed } \\
\text { by } 10 \% \text { sucrose in fixative }\end{array}$ & $\begin{array}{l}0.1 \mathrm{M} \text { sodium } \\
\text { phosphate }\end{array}$ & Pump & NR & $\begin{array}{l}\text { 10 I fixative only; } \\
4 \text { I } 10 \% \text { sucrose } \\
\text { in fixative }\end{array}$ & NR & $\begin{array}{l}\text { "Normal mean } \\
\text { arterial pressure" }\end{array}$ \\
\hline $\begin{array}{l}\text { Huang } 1993 \\
{[40]}\end{array}$ & $4 \%$ paraformaldehyde & $\begin{array}{l}0.1 \mathrm{M} \text { phosphate } \\
\text { buffer }\end{array}$ & NR & 83 mins & 101 & $\begin{array}{l}120 \mathrm{ml} / \\
\min \end{array}$ & NR \\
\hline $\begin{array}{l}\text { Insausti } 1995 \\
\text { [42] }\end{array}$ & $\begin{array}{l}\text { 4\% paraformaldehyde } \\
\left(4^{\circ} \mathrm{C}\right) \text { or } 4 \% \text { paraformaldehyde, } \\
0.02 \% \text { picric acid }\left(4^{\circ} \mathrm{C}\right)\end{array}$ & NR & NR & $\begin{array}{l}120 \\
\text { mins }\end{array}$ & $4 \mid$ or 81 & $\begin{array}{l}33 \text { or } \\
67 \mathrm{ml} / \\
\min \end{array}$ & NR \\
\hline $\begin{array}{l}\text { Istomin } \\
1994[43]\end{array}$ & $10-12 \%$ formalin & Neutral buffered & Syringe or Gravity & NR & NR & NR & $150 \mathrm{mmHg}$ \\
\hline $\begin{array}{l}\text { Kalimo } \\
1974[45]\end{array}$ & $\begin{array}{l}\text { 1.0\% paraformaldehyde, } \\
2.0 \% \text { glutaraldehyde }\left(37^{\circ} \mathrm{C}\right)\end{array}$ & $\begin{array}{l}0.1 \mathrm{M} \text { cacodylate } \\
(\mathrm{pH} 7.4)\end{array}$ & Gravity & NR & $\begin{array}{l}1.5 \text { I (adult), } \\
0.7 \text { I (newborn) }\end{array}$ & NR & $132 \mathrm{mmHg}$ \\
\hline $\begin{array}{l}\text { Latini } \\
2015 \text { [53] }\end{array}$ & $12 \%$ formalin & NR & $\begin{array}{l}\text { Infusion device } \\
\text { (compressed air } \\
\text { mechanism)* }\end{array}$ & $\begin{array}{l}15- \\
20 \text { min }\end{array}$ & 21 & $\begin{array}{l}100- \\
133 \mathrm{ml} / \\
\min \end{array}$ & $\begin{array}{l}1500 \mathrm{mmHg} \\
(200 \mathrm{kPa})\end{array}$ \\
\hline $\begin{array}{l}\operatorname{Lin} \\
2000[57]\end{array}$ & $\begin{array}{l}4 \% \text { paraformaldehyde, } 0.2 \% \text { picric } \\
\text { acid, and } 0.1 \% \text { glutaraldehyde }\end{array}$ & $\begin{array}{l}0.1 \mathrm{M} \text { phosphate } \\
\text { buffer ( } \mathrm{pH} 7.4)\end{array}$ & NR & NR & NR & NR & NR \\
\hline Lyck & $4 \%$ formalin & $75 \mathrm{mM}$ & NR & NR & NR & NR & NR \\
\hline
\end{tabular}


Table 4 Fixative solutions reported by the included studies (Continued)

\begin{tabular}{|c|c|c|c|c|c|c|c|}
\hline Study & Fixative solution & Buffer & Drive & Time & Amount & $\begin{array}{l}\text { Flow } \\
\text { rate }\end{array}$ & Pressure \\
\hline 2008 [58] & & $\begin{array}{l}\text { phosphate buffer } \\
\text { (pH 7.0) }\end{array}$ & & & & & \\
\hline $\begin{array}{l}\text { Masawa } \\
1993[59]\end{array}$ & $\begin{array}{l}4 \% \text { formalin, } \\
1 \% \text { glutaraldehyde }\end{array}$ & $\begin{array}{l}0.1 \mathrm{M} \text { phosphate } \\
\text { buffer ( } \mathrm{pH} 7.4)\end{array}$ & NR & NR & $400 \mathrm{ml}$ & NR & $100 \mathrm{mmHg}$ \\
\hline $\begin{array}{l}\text { Masawa } \\
1994[60]\end{array}$ & $10 \%$ buffered formalin & NR & $N R$ & $N R$ & $N R$ & NR & $100 \mathrm{mmHg}$ \\
\hline $\begin{array}{l}\text { McGeer } 1988 \\
\text { [62] }\end{array}$ & $\begin{array}{l}4 \% \text { paraformaldehyde, } \\
0.1 \% \text { glutaraldehyde }\end{array}$ & $\begin{array}{l}0.1 \% \text { phosphate } \\
\text { buffer ( } \mathrm{pH} 7.4 \text { ) }\end{array}$ & $N R$ & $N R$ & $N R$ & NR & NR \\
\hline $\begin{array}{l}\text { McKenzie } \\
1994[64]\end{array}$ & $10 \%$ formalin & Neutral buffered & Gravity & 60 mins & $12-14 \mid$ & $\begin{array}{l}200- \\
233 \mathrm{ml} / \\
\mathrm{min}\end{array}$ & $\begin{array}{l}75.6 \mathrm{mmHg} \\
\text { (height of } 1 \mathrm{~m} \text { ) }\end{array}$ \\
\hline $\begin{array}{l}\text { Nakamura } \\
1991 \text { [69] }\end{array}$ & $\begin{array}{l}4 \% \text { paraformaldehyde, } 0.1 \% \\
\text { glutaraldehyde (ice cold) }\end{array}$ & $\begin{array}{l}0.1 \mathrm{M} \text { phosphate } \\
\text { buffer ( } \mathrm{pH} 7.4 \text { ) }\end{array}$ & Pump & 15 mins & 11 & $\begin{array}{l}70-80 \\
\mathrm{ml} / \mathrm{min}\end{array}$ & NR \\
\hline $\begin{array}{l}\text { Pakkenberg } \\
1966[70]\end{array}$ & $\begin{array}{l}\text { Alcohol } 80 \% 9 \text { parts, } \\
\text { formalin } 4 \% 1 \text { part }\end{array}$ & NR & NR & NR & NR & NR & NR \\
\hline $\begin{array}{l}\text { Sharma } 2006 \\
\text { [79] }\end{array}$ & $20 \%$ formalin & Neutral buffered & $N R$ & $N R$ & $N R$ & NR & NR \\
\hline $\begin{array}{l}\text { Shinkai } \\
1976[81]\end{array}$ & $\begin{array}{l}2.5 \% \text { glutaraldehyde } \\
\text { containing } 0.2 \mathrm{M} \text { sucrose }\end{array}$ & $\begin{array}{l}0.1 \mathrm{M} \text { phosphate } \\
\text { buffer ( } \mathrm{pH} 7.4)\end{array}$ & NR & NR & NR & NR & NR \\
\hline $\begin{array}{l}\text { Sutoo } \\
1994 \text { [85] }\end{array}$ & $\begin{array}{l}4 \% \text { paraformaldehyde, } \\
0.2 \% \text { glutaraldehyde }\end{array}$ & PBS & $N R$ & 90 mins & 61 & $\begin{array}{l}67 \mathrm{ml} / \\
\min \end{array}$ & $N R$ \\
\hline $\begin{array}{l}\text { Suzuki } \\
1979[86]\end{array}$ & $2.5 \%$ glutaraldehyde & $\begin{array}{l}\text { Phosphate buffer } \\
(\mathrm{pH} 7.4)\end{array}$ & $N R$ & $\begin{array}{l}5- \\
10 \min \end{array}$ & $N R$ & NR & $N R$ \\
\hline $\begin{array}{l}\text { Tanaka } \\
1975[87]\end{array}$ & $\begin{array}{l}2 \% \text { glutaraldehyde, } 1 \% \\
\text { paraformaldehyde ( } \mathrm{pH} 7.2)\end{array}$ & $\begin{array}{l}0.1 \mathrm{M} \text { sodium } \\
\text { cacodylate }\end{array}$ & $N R$ & NR & 0.71 & NR & NR \\
\hline $\begin{array}{l}\text { Torack } \\
1990[90]\end{array}$ & $4 \%$ paraformaldehyde $\left(4^{\circ} \mathrm{C}\right)$ & $\begin{array}{l}0.1 \mathrm{M} \text { phosphate } \\
\text { buffer ( } \mathrm{pH} 7.4 \text { ) }\end{array}$ & NR & 30 mins & $\begin{array}{l}1.68 \mathrm{I}(560 \mathrm{ml} \text { in } \\
\text { each artery) }\end{array}$ & $\begin{array}{l}50 \mathrm{ml} / \\
\mathrm{min}\end{array}$ & $\begin{array}{l}\text { "40 lbs. of } \\
\text { pressure" }\end{array}$ \\
\hline $\begin{array}{l}\text { Turkoglu } \\
2014[92]\end{array}$ & $10 \%$ formaldehyde & NR & Gravity & 60 mins & $N R$ & NR & $\begin{array}{l}110.4 \mathrm{mmHg} \\
\text { (height of } 1.5 \mathrm{~m} \text { ) }\end{array}$ \\
\hline $\begin{array}{l}\text { von } \\
\text { Keyserlingk } \\
1984 \text { [93] }\end{array}$ & $\begin{array}{l}1 \% \text { paraformaldehyde, } \\
1 \% \text { glutaraldehyde, } \\
1.65 \% \text { potassium } \\
\text { dichromate }\end{array}$ & $\begin{array}{l}0.1 \mathrm{M} \text { cacodylate } \\
\text { buffer ( } \mathrm{pH} 7.4)\end{array}$ & $N R$ & $N R$ & 51 & NR & NR \\
\hline $\begin{array}{l}\text { Waldvogel } \\
2006[96]\end{array}$ & $15 \%$ formalin & $\begin{array}{l}0.1 \mathrm{M} \text { phosphate } \\
\text { buffer ( } \mathrm{pH} 7.4)\end{array}$ & Pump & $\begin{array}{l}30- \\
45 \min \end{array}$ & 21 & $\begin{array}{l}\sim 33 \\
\mathrm{ml} / \mathrm{min}\end{array}$ & NR \\
\hline $\begin{array}{l}\text { Welikovitch } \\
2018 \text { [99] }\end{array}$ & $\begin{array}{l}\text { 4\% paraformaldehyde, } \\
0.05 \% \text { glutaraldehyde, } \\
\text { and } 0.2 \% \text { picric acid }\end{array}$ & $\begin{array}{l}0.1 \mathrm{M} \text { phosphate } \\
\text { buffer }\end{array}$ & Gravity* & $\begin{array}{l}90- \\
120 \min \end{array}$ & $4-51$ & $\begin{array}{l}33-56 \\
\mathrm{ml} / \mathrm{min}\end{array}$ & $N R$ \\
\hline
\end{tabular}

This table lists the fixatives solutions and their buffers, amounts, times for perfusion, flow rates, methods for driving perfusate, and/or perfusion pressures that are reported by the included studies. If gravity was used to drive perfusate, we used the formula $P=\rho g h$, where $P=$ hydrostatic pressure, $\rho=$ density of substance (assumed equal to water), $g=$ gravitational acceleration, and $h=$ height, to calculate the pressure. Asterisks indicate personal communications. NR: Not reported, PBS: Phosphate-buffered saline

from $0.05 \%$ in Welikovitch et al. [99] to $2.5 \%$ in Shinkai et al. [81] and Suzuki et al. [86]. In general, adding glutaraldehyde to the fixative solution allows for improved tissue morphology preservation for electron microscopy [67], at the cost of decreased immunogenicity of antigens for immunohistochemistry [47]. However, at lower concentrations of glutaraldehyde, such as the $0.05 \%$ used in Welikovitch et al. [99], its effects on antigenicity are likely to not be as pronounced, and it likely acts primarily to slightly improve tissue morphology.

In addition to formaldehyde and glutaraldehyde, some investigators have used other fixatives. Picric acid, also known as 2,4,6-trinitrophenol, was used by Halliday et al. [35] (2\%), Insausti et al. [42] (0.02\%), Lin et al. [57] (0.2\%), and Welikovitch et al. [99] (0.2\%). Picric acid has been found to improve preservation of immunogenicity compared to aldehyde fixation alone [82], although safety concerns make this fixative less desirable due to its explosive properties.

Pakkenberg et al. [70] used a solution made up of 9 parts $80 \%$ alcohol and 1 part $4 \%$ formalin, which fixed the tissue to a quality sufficient for counting the number of nucleoli in the cortex, but also led to $20 \%$ volume shrinkage. This is consistent with the dehydrating effect 
of alcohol fixatives [39]. Other studies that used alcohol in their fixative solutions included Feekes et al. [28], Grinberg et al. [34], and Benet et al. [9].

Two of the studies used sucrose as a component of their perfused fixative solution, Shinkai et al. [81] and Halliday et al. [35]. The addition of sucrose might help to optimize the osmotic concentration of the perfusate $[13,98]$ and/or to act as a cryoprotectant to prevent tissue morphology changes due to ice damage during sectioning with a freezing microtome.

Donckaster et al. [24] perfused Cajal fixative, which consists of formalin and ammonium bromide. The addition of ammonium bromide is thought to facilitate silver staining of neural cells [52]. von Keyserlingk et al. [93] perfused 1\% paraformaldehyde, $1 \%$ glutaraldehyde, and $1.65 \%$ potassium dichromate. The addition of potassium dichromate has been found to aid in the fixation of lipids [38], which is consistent with the focus of von Keyserlingk et al. [93] on myelin ultrastructure.

Benet et al. [9] used a custom fixative composed of ethanol $62.4 \%$, glycerol $17 \%$, phenol $10.2 \%$, formaldehyde $2.3 \%$, and water $8.1 \%$, which they compared to a fixative with $10 \%$ formaldehyde for use in surgical simulation. They concluded that the custom fixative was superior for surgical simulation, in part because it caused less hardening and therefore allowed for more realistic tissue retraction.

Grinberg et al. [34] compared four different fixatives in their study. They found that perfusion of $20 \%$ formalin and acetic acid-alcohol-formaldehyde both led to efficient fixation of deep brain structures, while $10 \%$ formalin did not, and $70 \%$ ethanol did not harden at all. However, they found that the acetic acid-alcohol-formaldehyde fixative led to dissolution of myelin, while $20 \%$ formalin did not.

The fixative vehicle or buffer can also have important effects on tissue preservation [16]. The most common buffer in the studies we identified was phosphate buffer, which was reported in 19 of the studies. Phosphate buffer can be titrated to maintain an approximately neutral $\mathrm{pH}$, at which point the fixative solution can also be called "neutral-buffered." One of the most important aspects of the buffer is the molarity, which is thought to be the major driver of the osmotic concentration of the fixative solution [14]. Although there is some controversy on this point, aldehyde fixatives themselves are generally not considered major drivers of the osmotic concentration, as they easily cross semipermeable cell membranes, and therefore do not exert a sustained osmotic force [37]. As a result, the osmotic concentration of the fixative vehicle is called the effective osmotic concentration. Hypertonic fixative solutions can cause grossly shrunken brain tissue and cell shrinkage, whereas hypotonic solutions can cause edema and resistance to flow in the perfusion procedure [77].
It would be convenient to be able to identify the optimal vehicle osmotic concentration that would minimize osmotic tissue changes. However, Böhm [12] pointed out that the redistribution of fluids and ions during hypoxia makes it difficult to identify this optimal osmotic concentration in the postmortem state, which is consistent with more recent evidence $[46,51]$. To study this empirically, Böhm [12] used fixative solutions with multiple different osmolarities, finding that a mildly hypertonic solution with a total osmotic concentration of 500 mOsm and an effective osmotic concentration of 300 mOsm led to the best fixation quality in their study.

Several of the included studies manipulated the temperature of their fixative solution prior to perfusion. Beach et al. [7] cooled their fixative solution to be "ice-cold," while Torack et al. [90] and Insausti et al. [42] cooled their fixative solution to $4{ }^{\circ} \mathrm{C}$. Lower temperatures can help to inhibit metabolism and thereby mitigate tissue degradation, although it has also been reported to cause vasoconstriction [29]. One study, Kalimo et al. [45], perfused their fixative at the elevated temperature of $37^{\circ} \mathrm{C}$, which has been suggested to facilitate vasodilation and improve perfusion flow [29].

Taken together, 1-101 of phosphate-buffered formaldehyde was the most common fixative solution perfused. The most important determinants of the fixative are the assay of interest and the tissue or cell type of interest (e.g. neurons or myelin). The choice of fixative buffer is an important way to balance tissue shrinkage and swelling while the fixative is being perfused and can affect fixation quality.

\section{Driving perfusate and perfusion pressure}

The three major methods for driving the flow of solution during perfusion are syringes, gravity, and perfusion pumps. All three methods were reported by the included studies: 2 studies reported using a syringe, 8 studies reported using gravity, and 4 studies reported using a pump (Table 4). The majority of studies did not report their drive method. Upsides of a syringe are that it is easier to inject a specific amount of fluid in each vessel, while it is more difficult to control flow rate and pressure.

From the perspective of a perfusion circuit, the included studies were open-circuit in that they did not describe using a method for re-introducing the outflow of the perfusate back into the vessels. In the in situ approaches, the perfusate typically drained from the internal jugular veins after flowing through the carotid and/or vertebral circulatory systems. In the ex situ approaches, the perfusate would be expected to drain from the cerebral veins and/or ruptured vessels below the isolated brain, for example into a container. 
A major trade-off in setting the perfusion pressure is that too high of a perfusion pressure may lead to a higher risk of vessel rupture [76], while too low of perfusion pressure may lead to incomplete perfusion, decreased clot removal, and decreased tissue penetration of the fixative [17]. In laboratory animals, investigators often suggest that perfusion pressure should be maintained at roughly the same pressure that it was during life, which is called physiologic pressure [25, 30]. Consistent with this, Halliday et al. [35] and Coveñas et al. [20] reported that their perfusion pressures were "normal mean arterial pressure." Böhm [12] kept their perfusion pressure lower, in the range of $25.7 \mathrm{mmHg}$ $\left(35 \mathrm{~cm} \mathrm{H} \mathrm{H}_{2} \mathrm{O}\right)$ to $47.8 \mathrm{mmHg}\left(65 \mathrm{~cm} \mathrm{H} \mathrm{H}_{2} \mathrm{O}\right)$, because they were concerned that the endothelium is less stable postmortem than it is while the person is alive. However, Latini et al. [53] used the supraphysiologic pressure of 1500 $\mathrm{mmHg}(200 \mathrm{kPa})$ to study white matter anatomy, and they were able to preserve and dissect white matter blood vessels of submillimeter size.

Techniques using syringes, gravity, and perfusion pumps have all been employed to drive perfusion flow at a variety of different pressures. However, there were no studies that made comparisons between these alternative methods or identified an optimal perfusion pressure range for a particular application.

\section{Postfixation procedures}

In the context of perfusion fixation, "postfixation" refers to immersion fixation of the tissue sample for some amount of time following the initial perfusion, either in the original fixative or in a new fixative solution. The procedure for postfixation depends on whether the perfusion fixation was perfused in situ or ex situ (Table 5). If in situ, then the brain was often left in the skull for some amount of time to allow for fixative diffusion prior to removal. This time period ranged from $1 \mathrm{~h}$ in McKenzie et al. [64], 1 to $2 \mathrm{~h}$ in Kalimo et al. [45], and $2 \mathrm{~h}$ in von Keyserlingk et al. [93], to $48 \mathrm{~h}$ in Latini et al. [53].

Many of the studies reported cutting the brain prior to additional postfixation; for example, in Nakamura et al. [69], the tissue was cut into $1-2 \mathrm{~cm}$-thick coronal blocks. Perfusion-fixed tissue is harder and therefore easier to cut than fresh tissue. Cutting the tissue makes the subsequent immersion fixation process faster because there is a shorter distance for the fixatives to diffuse, with the obvious issue of damaging tissue at the cut interfaces.

There was a wide range of time frames used for postfixation, ranging from $4 \mathrm{~h}$ in Suzuki et al. [86] and 5-6 $\mathrm{h}$ in Adickes et al. (1997) [1] to 3 weeks in de Oliveira et al. [23] and Pakkenberg et al. [70] and 30 days in Coveñas et al. [20]. How long investigators chose to postfix for may depend in part on their perception of the quality of their perfusion fixation. One major advantage of postfixation is that it will allow for fixation even in regions of the brain where perfusion has been minimal or absent, for example as a result of persistent blood clots.

A key trade-off in the length of postfixation is that longer amounts of time will lead to better fixative penetration of deeper regions of the brain or tissue block, while it may also lead to over-fixation and decreased antigenicity in the outer regions of the brain (i.e., the cerebral cortex) or tissue block. As a result, a significant disadvantage of a long period of postfixation is that immunohistochemical staining and quantification will result in variable gradients across the tissue section. However, these gradients can be minimized by pre-processing steps that cut the tissue into smaller sections prior to postfixation. For example, Shinkai et al. [81] cut the tissue into $2 \mathrm{~mm}$ sections and Torack et al. [90] cut the tissue into $5 \mathrm{~mm}$ sections prior to postfixation.

The majority of the studies used the same fixative for perfusion fixation and postfixation. One exception is glutaraldehyde fixation studies, which typically omitted it from the postfixative, likely in order to mitigate further antigen masking. Another exception is three studies that prepared tissue samples for electron microscopy, Tanaka et al. [87], Masawa et al. (1993) [59], and von Keyserlingk et al. [93], which postfixed in osmium tetroxide, a fixative that stabilizes the ultrastructure of lipids and cell membranes [26].

In summary, postfixation is used commonly and it allows investigators to compensate for the possibility of poor perfusion quality. There was a wide range of postfixation procedures reported, ranging in time from a few hours to several weeks.

\section{Long-term storage methods}

Storing the brain in formaldehyde for the long-term prior to use is an economical and convenient way to prevent microbial and autolytic degradation. It is especially convenient for gross tissue preservation for surgical training, as was performed in Alvernia et al. [3] and Benet et al. [9]. However, for histology purposes, storage in formaldehyde has been found to lead to a decrease in antigenicity over time. Lyck et al. [58], who used this storage method, performed a quantitative study of several antigens over time, showing that antibody staining quality decreased for certain sensitive antigens, such as NeuN and CNPase, when stored in fixative over time. Similarly, McGeer et al. [62] noted that brains fixed in formalin for a long period of time had negative staining results for the protein that they were studying, HLA-DR.

An alternative method for long-term storage for subsequent histology is to store tissues at sub-zero temperatures. However, this method requires the distribution of cryoprotectant throughout the tissue to 
Table 5 Postfixation procedures reported by the included studies

\begin{tabular}{|c|c|c|c|c|c|}
\hline Study & Pre-processing & Fixative & Buffer & Temp & Length of postfixation \\
\hline $\begin{array}{l}\text { Adickes } \\
1996[2]\end{array}$ & NR & $10 \%$ buffered formalin & Phosphate & NR & 1 day (if postfixed) ${ }^{a}$ \\
\hline $\begin{array}{l}\text { Adickes } \\
1997[1]\end{array}$ & $\begin{array}{l}\text { Cut into } 1-1.5 \mathrm{~cm} \text {-thick } \\
\text { sections }\end{array}$ & $10 \%$ buffered formalin & Phosphate & NR & $5-6 h$ \\
\hline $\begin{array}{l}\text { von Keyserlingk } 1984 \\
\text { [93] }\end{array}$ & $\begin{array}{l}\text { Brain left in skull for } 2 \mathrm{~h} \text {, } \\
\text { then removed and dissected }\end{array}$ & $1 \%$ osmium tetroxide & $\begin{array}{l}0.1 \mathrm{M} \text { sodium } \\
\text { cacodylate }\end{array}$ & NR & $2 \mathrm{~h}$ \\
\hline $\begin{array}{l}\text { Istomin } \\
1994[43]\end{array}$ & NR & $10-12 \%$ formalin & Neutral-buffered & NR & NR \\
\hline $\begin{array}{l}\text { Beach } \\
1987[7]\end{array}$ & NR & $4 \%$ paraformaldehyde & $\begin{array}{l}0.1 \mathrm{M} \\
\text { phosphate } \\
\text { buffer ( } \mathrm{pH} 7.4 \text { ) }\end{array}$ & $4^{\circ} \mathrm{C}$ & NR \\
\hline $\begin{array}{l}\text { Benet } \\
2014[9]\end{array}$ & NR & 1:10 dilution of $10 \%$ formaldehyde & NR & $5^{\circ} \mathrm{C}$ & $>=2$ days \\
\hline $\begin{array}{l}\text { Benet } \\
2014[9]\end{array}$ & NR & $\begin{array}{l}1: 10 \text { dilution of } 10 \% \text { custom solution } \\
\text { (ethanol } 62.4 \% \text {, glycerol } 17 \% \text {, } \\
\text { phenol } 10.2 \% \text {, formaldehyde } \\
2.3 \% \text {, and water } 8.1 \% \text { ) }\end{array}$ & NR & $5^{\circ} \mathrm{C}$ & $>=2$ days \\
\hline $\begin{array}{l}\text { Böhm } \\
1983 \text { [12] }\end{array}$ & $\begin{array}{l}\text { Cut into } 1 \mathrm{~cm} \text {-thick coronal } \\
\text { sections }\end{array}$ & Paraformaldehyde or formalin & $\begin{array}{l}0.1 \mathrm{M} \\
\text { phosphate } \\
\text { buffer }\end{array}$ & NR & NR \\
\hline $\begin{array}{l}\text { Coveñas } \\
2003[20]\end{array}$ & NR & $4 \%$ paraformaldehyde & $\begin{array}{l}0.15 \mathrm{M} \text { PBS } \\
(\mathrm{pH} 7.2)\end{array}$ & $4^{\circ} \mathrm{C}$ & 30 days \\
\hline $\begin{array}{l}\text { de Oliveira } \\
2012 \text { [23] }\end{array}$ & NR & $20 \%$ formalin & NR & NR & 3 weeks \\
\hline $\begin{array}{l}\text { Donckaster } \\
1963[24]\end{array}$ & Brain removed & $\begin{array}{l}\text { Cajal fixative: formalin and } \\
\text { ammonium bromide }\end{array}$ & NR & NR & 4 days \\
\hline $\begin{array}{l}\text { Grinberg } \\
2008[34]\end{array}$ & NR & $\begin{array}{l}\text { Same fixative as was used for } \\
\text { fixation }\end{array}$ & NR & NR & NR \\
\hline $\begin{array}{l}\text { Huang } \\
1993[40]\end{array}$ & Dissection of brainstem & NR & NR & NR & $<=24 \mathrm{~h}$ \\
\hline $\begin{array}{l}\text { Insausti } \\
1995[42]\end{array}$ & $\begin{array}{l}\text { Dissected into slabs approximately } \\
1 \mathrm{~cm} \text { thick }\end{array}$ & 4\% paraformaldehyde & NR & NR & $48-72 h$ \\
\hline $\begin{array}{l}\text { Kalimo } \\
1974 \text { [45] } \\
\text { (electron microscopy) }\end{array}$ & $\begin{array}{l}\text { Brain left in the skull for } \\
1 \text { to } 2 \mathrm{~h} \text { after perfusion fixation, } \\
\text { then removed, then samples } \\
\text { dissected for EM }\end{array}$ & $\begin{array}{l}1.0 \% \text { paraformaldehyde, } 2.0 \% \\
\text { glutaraldehyde }\end{array}$ & $\begin{array}{l}0.1 \mathrm{M} \\
\text { cacodylate (pH } \\
7.4)\end{array}$ & NR & Overnight \\
\hline $\begin{array}{l}\text { Kalimo } \\
1974 \text { [45] (histology) }\end{array}$ & Same as above & 10\% formaldehyde & NR & NR & 10 days \\
\hline Latini 2015 [53] & $\begin{array}{l}\text { Brain extracted from the skull } \\
48 \mathrm{~h} \text { after perfusion }\end{array}$ & $10 \%$ formalin & NR & NR & $24 \mathrm{~h}$ \\
\hline Lin 2000 [57] & NR & $4 \%$ paraformaldehyde & $\begin{array}{l}0.1 \mathrm{M} \\
\text { phosphate } \\
\text { buffer (pH 7.4) }\end{array}$ & $4^{\circ} \mathrm{C}$ & Overnight \\
\hline Lyck 2008 [58] & Brain removed from skull & $4 \%$ paraformaldehyde & $\begin{array}{l}0.15 \mathrm{M} \\
\text { Sørensens } \\
\text { phosphate } \\
\text { buffer (pH 7.4) }\end{array}$ & $4^{\circ} \mathrm{C}$ & 2 weeks \\
\hline Masawa 1993 [59] & NR & $4 \%$ formalin & $\begin{array}{l}0.1 \mathrm{M} \\
\text { phosphate } \\
\text { buffer }\end{array}$ & NR & $>=3$ days \\
\hline $\begin{array}{l}\text { Masawa } 1993 \text { [59] } \\
\text { (electron microscopy) }\end{array}$ & $\begin{array}{l}\text { From postfixed tissue, } \\
\text { tissue blocks were cut and } \\
\text { buffer washed }\end{array}$ & $1 \%$ osmium tetroxide solution & NR & $4^{\circ} \mathrm{C}$ & $90 \mathrm{~min}$ \\
\hline McGeer 1988 [62] & NR & 4\% paraformaldehyde & NR & NR & $\begin{array}{l}2-3 \text { days or until the } \\
\text { pink color of unfixed } \\
\text { erythrocytes was gone }\end{array}$ \\
\hline
\end{tabular}


Table 5 Postfixation procedures reported by the included studies (Continued)

\begin{tabular}{|c|c|c|c|c|c|}
\hline Study & Pre-processing & Fixative & Buffer & Temp & Length of postfixation \\
\hline McKenzie 1994 [64] & $\begin{array}{l}\text { Waited } 1 \mathrm{~h} \text { after perfusion } \\
\text { fixation, then the skull was opened, } \\
\text { and the brain was removed }\end{array}$ & Formalin & Neutral-buffered & $4^{\circ} \mathrm{C}$ & NR \\
\hline Pakkenberg 1966 [70] & Brain removed from skull & $\begin{array}{l}\text { Alcohol } 80 \% 9 \text { parts, formalin } \\
4 \% 1 \text { part }\end{array}$ & NR & NR & 3 weeks \\
\hline Sharma 2006 [79] & Brain suspended in a bucket & $20 \%$ formalin & Neutral-buffered & NR & $1-4$ days \\
\hline Shinkai 1976 [81] & Cut into $2 \mathrm{~mm}$-thick tissue blocks & $\begin{array}{l}2.5 \% \text { glutaraldehyde } \\
\text { containing } 0.2 \mathrm{M} \text { sucrose }\end{array}$ & NR & NR & $4-8 h$ \\
\hline Sutoo 1994 [85] & $\begin{array}{l}\text { Brain halved sagittally and sliced } \\
\text { into } 10 \mathrm{~mm} \text { coronal blocks }\end{array}$ & $4 \%$ paraformaldehyde & PBS & $4^{\circ} \mathrm{C}$ & 2 days \\
\hline Suzuki 1979 [86] & $\begin{array}{l}\text { Dissected bifurcations of the first } \\
\text { temporal branches of the } \\
\text { middle cerebral arteries }\end{array}$ & $2.5 \%$ glutaraldehyde & NR & NR & $4 \mathrm{~h}$ \\
\hline $\begin{array}{l}\text { Tanaka } 1975 \text { [87] } \\
\text { (electron microscopy) }\end{array}$ & $\begin{array}{l}\text { Samples taken from various } \\
\text { regions of the brain }\end{array}$ & $1.0 \%$ osmium tetroxide & NR & NR & NR \\
\hline $\begin{array}{l}\text { Tanaka } 1975 \text { [87] } \\
\text { (histology) }\end{array}$ & Rest of the brain & $8.0 \%$ formaldehyde & NR & NR & NR \\
\hline Torack 1990 [90] & $\begin{array}{l}\text { Hippocampus and entorhinal } \\
\text { cortex was isolated and sectioned } \\
\text { into } 0.5 \mathrm{~cm} \text { thick slices }\end{array}$ & $\begin{array}{l}4 \% \text { paraformaldehyde }+/- \\
1 \% \text { Bouin's solution (picric acid, } \\
\text { acetic acid, and formaldehyde) }\end{array}$ & NR & NR & $48 \mathrm{~h}$ \\
\hline Turkoglu 2014 [92] & Brain removed from skull & $10 \%$ formaldehyde & NR & NR & 2 weeks \\
\hline Waldvogel 2006 [96] & NR & $15 \%$ formalin & $\begin{array}{l}0.1 \mathrm{M} \\
\text { phosphate } \\
\text { buffer (pH 7.4) }\end{array}$ & NR & $6-12 \mathrm{~h}$ \\
\hline Welikovitch 2018 [99] & $\begin{array}{l}\text { Dissected out the medial } \\
\text { temporal lobe }\end{array}$ & $\begin{array}{l}4 \% \text { paraformaldehyde and } \\
0.2 \% \text { picric acid }\end{array}$ & $\begin{array}{l}0.1 \mathrm{M} \\
\text { phosphate } \\
\text { buffer }\end{array}$ & NR & Overnight \\
\hline
\end{tabular}

${ }^{a}$ : Note that in Adickes et al. (1996), the brain is either cut immediately or postfixed in formalin for one day. NR: Not reported, PBS: Phosphate-buffered saline

Table 6 Strategies for long-term storage of perfusion-fixed brain tissue

\begin{tabular}{|c|c|c|c|c|c|c|}
\hline Study & Overall method & Study type & Tissue & Preservative agent(s) & Temperature & $\begin{array}{l}\text { Storage } \\
\text { duration }\end{array}$ \\
\hline $\begin{array}{l}\text { Alvernia } 2010 \\
\text { [3] }\end{array}$ & Immersion in fixative & $\begin{array}{l}\text { Surgical } \\
\text { training }\end{array}$ & Separated head & $10 \%$ Formalin and $10 \%$ ethyl alcohol & $4{ }^{\circ} \mathrm{C}$ & $\begin{array}{l}\text { Up to } 4 \\
\text { years }\end{array}$ \\
\hline Benet 2014 [9] & Immersion in fixative & $\begin{array}{l}\text { Surgical } \\
\text { training }\end{array}$ & Separated head & $\begin{array}{l}10 \% \text { formaldehyde or } 10 \% \text { custom } \\
\text { solution (ethanol } 62.4 \% \text {, glycerol } 17 \% \text {, } \\
\text { phenol } 10.2 \% \text {, formaldehyde } 2.3 \% \text {, } \\
\text { and water } 8.1 \% \text { ) }\end{array}$ & $5^{\circ} \mathrm{C}$ & Up to a year \\
\hline $\begin{array}{l}\text { Insausti } \\
1995[42]\end{array}$ & $\begin{array}{l}\text { Cryoprotection and } \\
\text { freezing }\end{array}$ & Histology & $\begin{array}{l}1 \mathrm{~cm} \text {-thick coronal } \\
\text { tissue blocks }\end{array}$ & $\begin{array}{l}\text { Solutions of } 10 \text { and } 20 \% \text { glycerol } \\
\text { in } 0.1 \mathrm{M} \text { phosphate buffer and } \\
2 \% \text { dimethylsulfoxide }\end{array}$ & $-80^{\circ} \mathrm{C}$ & NR \\
\hline Lyck 2008 [58] & Immersion in fixative & Histology & Whole brain & $\begin{array}{l}0.1 \% \text { paraformaldehyde in } 0.15 \mathrm{M} \\
\text { Sørensens phosphate buffer }(\mathrm{pH} 7.4)\end{array}$ & $4{ }^{\circ} \mathrm{C}$ & $\begin{array}{l}\text { Up to } 4 \\
\text { years }\end{array}$ \\
\hline Sutoo 1994 [85] & $\begin{array}{l}\text { Cryoprotection and } \\
\text { freezing }\end{array}$ & Histology & $\begin{array}{l}1 \mathrm{~cm} \text {-thick coronal } \\
\text { tissue blocks }\end{array}$ & Buffered $5 \%$ sucrose & $-80^{\circ} \mathrm{C}$ & NR \\
\hline $\begin{array}{l}\text { Waldgovel } \\
2006[96]\end{array}$ & $\begin{array}{l}\text { Cryoprotection and } \\
\text { freezing }\end{array}$ & Histology & $\begin{array}{l}\text { Tissue blocks (many } 1 \\
\text { cm-thick) }\end{array}$ & $\begin{array}{l}20-30 \% \text { sucrose in } 0.1 \mathrm{M} \text { phosphate } \\
\text { buffer with } 0.1 \% \text { sodium azide }\end{array}$ & $-80^{\circ} \mathrm{C}$ & NR \\
\hline $\begin{array}{l}\text { Welikovitch } \\
2018 \text { [99] }\end{array}$ & $\begin{array}{l}\text { Cryoprotection and } \\
\text { freezing }\end{array}$ & Histology & Brain sections & $\begin{array}{l}1.1 \mathrm{M} \text { sucrose, } 37.5 \% \text { ethylene glycol } \\
\text { in PBS }\end{array}$ & $-20^{\circ} \mathrm{C}$ & NR \\
\hline
\end{tabular}

If a study did not report the use of a long-term storage method, then it is not included in this table. NR: Not reported, PBS: Phosphate-buffered saline 
prevent ice damage. Four studies reported using this method for long-term storage (Table 6). Notably, the glycerol-dimethylsulfoxide cryoprotectant method used by Insausti et al. [42] has been found in non-human primate brain tissue to cause less tissue shrinkage than the sucrose-based methods [27].

To summarize, fixed brain tissue can be stored in fixative at refrigerator temperatures near $4{ }^{\circ} \mathrm{C}$, but this will likely lead to a decrease in antigenicity over time. An alternative approach, which may allow for the preservation of antigenicity for longer, is to add cryoprotectant to the fixed brain tissue and store it at a freezer temperature such as $-80^{\circ} \mathrm{C}$.

\section{Comparisons of perfusion fixation with immersion fixation \\ Study selection}

For 6 studies, at least two reviewers agreed that the study made an explicit comparison between immersion and perfusion fixation. For one of these studies, Adickes et al. (1996) [2], this outcome was graded as "low quality" on the basis of our risk of bias appraisal tool, as all of the applicable components for risk of bias were either graded as "unclear" or "no." Therefore this study was removed, leaving 5 studies (Table 7).

\section{Methodologies and results of included studies}

Adickes et al. (1997) [1] performed a type of crossover study, using immersion and perfusion fixation on each hemisphere of the same autopsied brains. Sharma et al.
[79] randomly selected slides from brain tissue that had previously been fixed with either immersion or perfusion fixation and then did prospective analysis of their histology quality via blinded reviewers. These are both considered optimal methodologies that were considered equivalent to a randomized study. The other 3 studies did not describe their methods for allocating donor brains to different interventions and were classified as non-randomized experimental studies.

The outcome described by the 4 of the studies, Adickes et al. (1997) [1], Beach et al. [7], Grinberg et al. [34], and Sharma et al. [79] was the immediate subjective histology quality following a perfusion fixation procedure compared to an immersion fixation procedure. Because the Sharma et al. [79] and Adickes et al. (1997) [1] studies had more optimal study methodologies, their results were weighted higher in the grading process in evaluating this outcome. The outcome of Lyck et al. [58] addressed antigen staining results for brain samples stored in fixative long-term that were initially perfusion fixed compared to those initially immersion fixed.

For the outcome of immediate subjective histology quality, Adickes et al. (1997) [1] found equal or superior histology quality in perfusion-fixed tissue, Sharma et al. [79] found no significant difference, while Grinberg et al. [34] and Beach et al. [7] found improved histology quality in perfusion-fixed tissue, especially in deep brain regions. Notably, the immersion fixation protocol was performed on the whole brain in Grinberg et al. [34] and Sharma

Table 7 Description of studies with an explicit comparison between perfusion and immersion fixation

\begin{tabular}{|c|c|c|c|c|c|c|c|}
\hline \multirow[t]{2}{*}{ Study } & \multirow[t]{2}{*}{ Design } & \multicolumn{2}{|c|}{$\begin{array}{l}\text { Number of brains } \\
\text { fixed }\end{array}$} & \multicolumn{2}{|c|}{ Time for procedure } & \multirow[t]{2}{*}{ Outcome } & \multirow[t]{2}{*}{ Result } \\
\hline & & Perfusion & Immersion & Perfusion & Immersion & & \\
\hline $\begin{array}{l}\text { Adickes } \\
1997[1]\end{array}$ & Crossover, within-brain & 4 & 4 & $5-6 h$ & 2 weeks & $\begin{array}{l}\text { Subjective } \\
\text { histology quality }\end{array}$ & $\begin{array}{l}\text { Equal or superior tissue preservation } \\
\text { with perfusion fixation compared } \\
\text { with immersion fixation }\end{array}$ \\
\hline $\begin{array}{l}\text { Beach } 1987 \\
\text { [7] }\end{array}$ & Experimental, non-randomized & 2 & 2 & $1-8$ days & $1-8$ days & $\begin{array}{l}\text { Subjective } \\
\text { histology quality }\end{array}$ & $\begin{array}{l}\text { More even distribution of staining } \\
\text { in perfusion-fixed samples, } \\
\text { while immersion fixed samples had } \\
\text { a dense band of staining at the edges } \\
\text { of the fixed tissue and pale regions } \\
\text { in the interior }\end{array}$ \\
\hline $\begin{array}{l}\text { Grinberg } \\
2008[34]\end{array}$ & Experimental, non-randomized & 32 & 4 & $\begin{array}{l}\text { Not } \\
\text { reported }\end{array}$ & $\begin{array}{l}>3 \\
\text { months }\end{array}$ & $\begin{array}{l}\text { Subjective } \\
\text { histology quality }\end{array}$ & $\begin{array}{l}\text { More uniform penetration of fixative } \\
\text { agent into all regions of the brain } \\
\text { in perfusion-fixed samples, including } \\
\text { deep regions such as the thalamus } \\
\text { and basal ganglia }\end{array}$ \\
\hline $\begin{array}{l}\text { Lyck } 2008 \\
{[58]}\end{array}$ & Experimental, non-randomized & 32 & 5 & $\begin{array}{l}1 \text { day - } 4 \\
\text { years }\end{array}$ & $\begin{array}{l}1 \text { day - } 10 \\
\text { years }\end{array}$ & $\begin{array}{l}\text { Long-term } \\
\text { immunostaining }\end{array}$ & $\begin{array}{l}\text { Better preservation of sensitive } \\
\text { antigens (e.g., NeuN and CNPase) } \\
\text { in perfusion-fixed specimens }\end{array}$ \\
\hline $\begin{array}{l}\text { Sharma } \\
2006[79]\end{array}$ & $\begin{array}{l}\text { Experimental, randomized } \\
\text { selection of brain tissue }\end{array}$ & 36 & 36 & $1-4$ days & 3-4 weeks & $\begin{array}{l}\text { Subjective } \\
\text { histology quality }\end{array}$ & $\begin{array}{l}\text { No significant difference in } \\
\text { staining quality between } \\
\text { perfusion and immersion fixation }\end{array}$ \\
\hline
\end{tabular}

Note that "histology quality" refers to visual microscopy results, including slides that have been stained with dyes as well as with antibody staining. Regarding the time for the procedure, note that in Beach et al. [7], the tissue was sliced into $1 \mathrm{~cm}$-thick blocks prior to the postfixation or initial immersion fixation. In Lyck et al. [58], the time reported includes the time for long-term storage in fixative beyond the initial fixation procedure 
et al. [79], one hemisphere in Adickes et al. (1997) [1], and $1 \mathrm{~cm}$-thick blocks in Beach et al. [7]. Sharma et al. [79] used a scoring system in which staining from conventional fixed brains was taken as the gold standard, which we believe refers to immersion fixed brain tissue. For Adickes et al. (1997) [1] and Sharma et al. [79], the perfusion fixation protocol was also completed much faster than the immersion fixation protocol. Overall, these results can be summarized as showing that there is equal or superior subjective histology quality in perfusion-fixed samples in an equal or shorter amount of time, when compared to immersion fixation of relatively large volumes of brain tissue, such as the whole brain, one brain hemisphere, or 1 $\mathrm{cm}$-thick tissue sections. When we mention time in this context, we are referring to the total time for the brain tissue to bathe in fixative during immersion fixation or postfixation before it is ready for downstream studies. In contrast, the time required for a trained worker to perform the procedure will almost certainly be longer for the perfusion-based methods.

For the outcome of immunostaining in samples stored in fixative long-term, Lyck et al. [58], found that there was better preservation of sensitive antigens (e.g., NeuN and CNPase) in perfusion-fixed specimens compared to immersion-fixed samples.

\section{Risk of bias assessment}

During the data extraction process, at least two independent reviewers appraised the included studies on the JBI quality metrics (Fig. 3). Three of the studies reported blinding of the histology quality assessors, while this was not mentioned for the other two studies. For the confounding question, Beach et al. [7] and Sharma et al. [79] did not report on enough demographic and clinical data that would allow us to determine whether the brain tissue was of substantially similar quality prior to the procedures. Lyck et al. [58] had their brain tissue from different brain banks and the PMIs also differed substantially between the perfusion and immersion fixation groups. Lyck et al. [58] also used different processing on the immersion- and perfusion-fixed tissue, such as storing the brains at room temperature and the perfusion-fixed brains at $4{ }^{\circ} \mathrm{C}$, which introduced another source of confounding bias. Overall, using our predefined summary of the risk of bias questionnaire, all five of the studies were assessed as being "high quality."

\section{Evidence grading}

For the outcome of subjective histology quality immediately following the procedures, we assigned an evidence grade of moderate quality (Table 8 ). Because of the study methodologies of Adickes et al. (1997) [1] and Sharma et al. [79], the evidence grade started at high quality. The reason for downgrading this to moderate was imprecision, which came in two forms. First, the sample sizes were relatively small, especially in Adickes et al. (1997) [1] and Beach et al. [7], which used only 4 brains

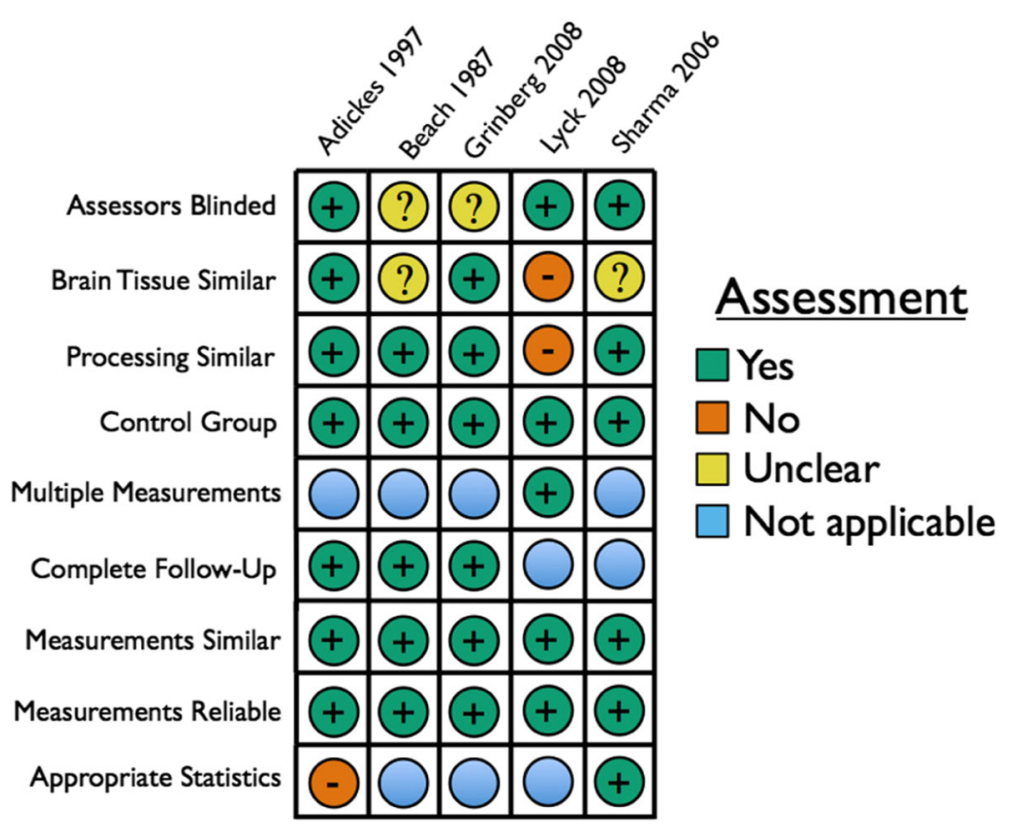

Fig. 3 Risk of bias assessment for the studies comparing perfusion to immersion fixation. We used a modified version of the Joanna Briggs Institute $(J B \mid)$ questionnaire for non-randomized experimental studies 
Table 8 Summary of findings for the two outcomes from comparing perfusion fixation and immersion fixation identified in our review

\begin{tabular}{lllll}
\hline Outcome & Number of studies & $\begin{array}{l}\text { Number of brain } \\
\text { samples }\end{array}$ & Overall effect & $\begin{array}{l}\text { Quality of the evidence } \\
\text { (GRADE) }\end{array}$ \\
\hline Subjective histology quality & $\begin{array}{l}4 \text { (1 randomized, } 1 \\
\text { crossover) }\end{array}$ & 116 & $\begin{array}{l}\text { Equal or superior histology quality in } \\
\text { perfusion-fixed tissues when compared } \\
\text { to immersion fixation of relatively }\end{array}$ & $\begin{array}{l}\oplus \oplus \oplus \odot \\
\text { large volumes of brain tissue }\end{array}$ \\
$\begin{array}{l}\text { Long-term immunostaining } \\
\text { quality }\end{array}$ & 137 & $\begin{array}{l}\text { Slower long-term degradation of antigen } \begin{array}{l}\oplus \odot \odot \\
\text { staining quality for sensitive antigens } \\
\text { in perfusion-fixed tissue }\end{array} \\
\text { VERY LOW }\end{array}$
\end{tabular}

In the GRADE quality assessment system, there are four levels of quality: high, moderate, low, and very low

each. Second, while experts such as neuropathologists assessed the histology quality grades, these scores are semiquantitative. Future work that identifies and quantifies particular features present in each of the histology images would allow for more precise testing of differences in fixation quality between the different methods.

Aside from the time required to perform perfusion fixation and possible osmotic or hydrostatic effects on tissue resulting from the perfusion process, the main difference between perfusion fixation and immersion fixation is in the time needed for postfixation. Therefore, perfusion fixation can be thought of as a shift along the fixation time-fixation quality curve, such that there is an improvement of histology quality following a given duration of immersion fixation or postfixation. This strength of this shift will vary based on the quality of the perfusion fixation. In the extreme case of ideal perfusion fixation, postfixation may not be necessary, but human brain tissue quality is often compromised by the time it reaches a brain bank, for example by a long PMI, which will typically prevent ideal perfusion fixation.

For the outcome of long-term immunostaining quality in initially perfusion-fixed or immersion-fixed brain tissue stored in fixative, the one study identified, Lyck et al. [58], found that there was less long-term degradation of antigen staining quality for sensitive antigens in perfusion-fixed tissue. We assigned this outcome an evidence grade of very low quality based on the available evidence (Table 8) because of serious concerns of imprecision from low sample size ( $n=5$ perfusion-fixed brains), as well as serious concerns of confounding from heterogeneous tissue processing.

\section{Informal comparisons reported between immersion and perfusion fixation}

The studies that did not make a formal comparison between immersion and perfusion fixation or were assessed as having a low-quality study design regarding this comparison, often remarked on differences between these two fixation methods. Adickes et al. (1996) [2] noted that histology quality was "excellent" in perfusion- fixed tissue and was better than tissue fixed en bloc via immersion. Kalimo et al. [45] reported that perfusion fixation led to higher quality cellular and tissue-level preservation than immersion fixation, especially in deep brain regions. Insausti et al. [42] reported that perfusion fixation led to faster and more homogenous fixation. Von Keyserlingk et al. [93] noted that perfusion fixation had a more "satisfying" ultrastructural preservation of myelin in preliminary studies compared to immersing the brain in $5 \%$ formaldehyde. Torack et al. [90] reported that it was possible to identify dopaminergic fibers in the hippocampus via their perfusion fixation method, similar to observations in rodent studies, but not previously identified in immersion-fixed tissue. These informal comparisons support the use of perfusion fixation for the most complete fixation of brain tissue, although the purpose and aims of the study should be evaluated individually while determining the fixation method.

\section{Comparison to other reviews}

To the best of our knowledge, there has not been a previous systematic review focused on the topic of perfusion fixation in human brain tissue. There has been a previous systematic review of perfusion techniques for surgical training [8]; however, it did not focus on perfusion fixation and histology quality in particular. One narrative review of one institution's experience with brain banking notes that perfusion fixation is the optimal method, but that it is time-consuming and that immersion fixation of $1 \mathrm{~cm}$-thick blocks at $4{ }^{\circ} \mathrm{C}$ is a reasonable alternative [6]. A response to Adickes et al. (1997) [1] by Miller [66] pointed out problems with perfusion fixation including artifactual perivascular pallor on myelin staining, difficulty in perfusion in the presence of ischemic infarcts or hemorrhagic tissue, and potentially increased exposure to formalin vapors. Another narrative review that was not specific to brain tissue noted that the literature contains conflicting evidence about whether perfusion fixation yields improved morphologic quality when compared to immersion fixation [4].

One book chapter by Connolly et al. [19] describes experience that perfusion speeds the fixation process 
and can improve immunohistochemical staining. However, corroborating one of the critiques of Miller [66], they note that perfusion fixation can occasionally cause irregular white matter pallor on hematoxylin and eosin stain that is likely artifactual. Connolly et al. [19] also note that in the presence of vascular diseases such as atherosclerosis, inadvertent damage to the circle of Willis during brain removal, and/or in cases of suspected cerebral emboli or thrombi, perfusion fixation can be difficult or even impossible. Another book chapter by Giannini et al. [32] also discusses experience in perfusion fixation of human brain tissue. They note that perfusion improves fixation of deeper regions of the brain. Giannini et al. [32] also point out several potential problems with perfusion fixation, including inducing gross asymmetry due to uneven perfusion of too much fixative in cases of an infarct, hemorrhage, or metastasis, artifactual dilatation of small blood vessels, and microscopic evidence of perivascular tissue rarefaction.

\section{Limitations of this review}

One limitation of this review is the potential for publication bias. Immersion fixation is the standard method for brain banking via fixation, which means there is less incentive for authors to publish articles showing that immersion fixation is superior to perfusion fixation. Perfusion fixation critiques were found in less formal media, such as textbook chapters or short review articles. While this is less likely to affect our outcome grades because we did not find evidence that any studies explicitly comparing perfusion and immersion fixation were not published, it is important when considering the positive tone that many of the authors have towards the use of their own methods.

Furthermore, we certainly underestimated the total number of studies of perfusion fixation for human brain tissue preservation. One major reason for this is because we searched titles and abstracts rather than full-texts. Through ad hoc reviews of the literature, we were able to identify multiple studies $[41,83,89]$ that used perfusion fixation in human brain banking but did not describe it in the title or abstract. However, as additional studies would have had diminishing returns in the variance of their methods employed, our review is still likely to have good coverage of the types of methods that have been used.

Finally, multiple changes were made to the protocol after the initiation of the review process. As a part of this, we did not pre-specify the outcomes to grade for methods comparison, which means that our choice of outcomes to grade could be more influenced by our biases based on their direction of effect. In part this is due to the relative paucity of previous literature on human brain perfusion fixation. This meant that we started the review process with relatively little knowledge of what types of data we would encounter and what types of outcomes would be reported and possible to grade.

\section{Recommendations for further research}

One of the areas in which more research could make a major contribution is comparison between perfusion fixation methods. For example, on the broadest level, it would be interesting to see whether there is higher histology quality in the in situ approaches, which minimize mechanical trauma and blood vessel damage, or the ex situ approaches, which allow for direct monitoring of the washout and fixation procedures and may be more robust to raised intracranial pressure. Comparisons between different washout solutions would also be valuable, as the accumulation of perimortem clots that frequently occlude perfusion is relatively unique to human brain banking [36]. For example, it might be useful to test whether washout with reagents used in perfusing transplant organs, such as fibrinolytic agents [56], might allow for improvements in perfusion fixation. Additionally, if it is possible to develop perfusion fixation methods that are less expensive, time-consuming, and/or technically challenging compared to immersion fixation, this may help more brain banks to adopt the method.

The comparison studies that we identified in this review all performed immersion fixation on relatively large volumes of brain tissue, with a minimum size of $1 \mathrm{~cm}$ thick tissue blocks. Further research could evaluate the extent to which slicing the tissue into smaller volumes, such as a thickness of $5 \mathrm{~mm}$ or less, prior to immersion fixation might allow for improved histology quality compared to perfusion fixation. In addition, it may be possible to accelerate immersion fixation through other approaches, such as using high-frequency ultrasound to enhance fixative delivery [18].

Another area for improvement of perfusion fixation as a brain banking procedure is in improving methods for the long-term storage of fixed brain tissue. For example, a study could compare different cryoprotectants for preserving human tissue morphology and antigenicity in slices at low temperature, as has been performed in non-human primate brain tissue [27]. Another useful storage method could involve perfusing cryoprotectants after the fixative perfusion, to facilitate storage of intact brain tissue at low temperatures $[63,65]$. This would potentially allow for more detailed studies of cross-region neuronal connectivity or ex situ neuroimaging with fewer batch effects resulting from long-term storage in formalin. Regarding ex situ neuroimaging, another question for future research is whether images taken from brains fixed with perfusion 
would allow for a higher correlation with pre-mortem images than brains fixed with immersion.

Some of the included studies and reviews of this topic suggested that perfusion fixation should not be performed on brain tissue with certain characteristics, such as cerebrovascular disease or long PMI. However, these claims are often not supported by direct data, and other studies cast doubt upon some of them; for example, Waldvogel et al. [96] noted the relative importance of periagonal factors as opposed to the PMI in determining immunohistochemical staining quality. Further research that characterized the types of brain tissue in which it is beneficial to use perfusion fixation as opposed to immersion fixation would be valuable.

\section{Conclusions}

Our systematic review of perfusion fixation for human brain banking discovered that a wide variety of methods have been used. The earliest studies reporting human brain perfusion fixation primarily used the in situ approach, but since the mid-1970s, the ex situ approach has become more common. In order to allow half of the brain to be frozen for biomolecular or biochemical studies, a more recent innovation over the past two decades has been to perform perfusion fixation on only one isolated hemisphere of the brain. For neuropathologists and investigators in brain banks, we identified moderate quality evidence that perfusion fixation leads to equal or higher subjective histology quality in relatively large volumes of brain tissue, while taking equivalent or less time than immersion fixation. However, perfusion fixation has been reported to have some downsides, including potential for tissue edema or uneven fixation in the presence of cerebrovascular disease. Furthermore, there are substantial logistical, technical, and financial challenges involved in perfusion fixation that are not required by the relatively simple method of immersion fixation. Improvements in the methods for perfusion fixation of human brain tissue would allow for novel investigations of human brain disease pathophysiology, such as highresolution ex vivo neuroimaging, spatial biomolecular profiling, circuit tracing, and connectome studies.

For investigators running brain banks interested in using perfusion fixation, we can offer a few suggestions. First, it is important to acknowledge that many of the recent advances in our understanding of the pathophysiology of brain disease have come from studying frozen unfixed tissue $[15,49]$. As a result, frozen unfixed tissue will remain a critical component of most brain banking protocols. For investigators who desire to bank a substantial amount of fresh unfixed tissue, the ex situ one hemisphere approach, despite its limitations, is the only feasible option. On the other hand, for investigators who are exclusively interested in studying fixed brain tissue, either the in situ or ex situ approaches may be worthwhile to consider. If minimal technical challenge is desired, then an ex situ approach employing gravity to drive the perfusion of standard formalin fixative for around 15 min may be sufficient. On the other hand, if procedural time and resources are less of a constraint, then using a washout step and choosing a fixative solution optimized for the desired downstream studies may be helpful. If severe vascular pathology such as hemorrhage is present in a focal area of the brain, then perfuse the contralateral hemisphere or avoid perfusion fixation in that brain altogether. Overall, perfusion fixation is an appropriate method to use for higher quality fixation of deep structures and possible improved immunogenicity. The overall choice will depend upon the goals and available resources of each investigator and brain bank.

\section{Additional files}

Additional file 1: PRISMA checklist for the study. (PDF $109 \mathrm{~kb}$ )

Additional file 2: Database search methods. (PDF 48 kb)

Additional file 3: Data extraction form and study appraisal tool. (PDF $50 \mathrm{~kb}$ )

\section{Abbreviations}

GRADE: Grading of Recommendations, Assessment, Development, and Evaluations; IJV: Internal jugular vein; JBI: Joanna Briggs Institute; kPa: Kilopascals; mOsm: Milliosmole; NR: Not reported; PBS: Phosphate-buffered saline; PCOA: Posterior communicating artery; PMI: Postmortem interval;

PRISMA: Preferred Reporting Items for Systematic Reviews and Meta-Analyses

\section{Acknowledgements}

We would like to thank Glenda Halliday, Helmut Heinsen, Henry Waldvogel, Kátia Cristina de Oliveira, Maglóczky Zsófia, Ricardo Insausti, and Thomas Beach for helpful personal communications regarding their methods and experiences using perfusion fixation in human brain banking.

\section{Authors' contributions}

W.C.M., C.S., and A.T.M. designed the study. C.S. performed the database searches. W.C.M. and A.T.M. performed abstract and article screening. W.C.M., H.W., C.H.B., F.R., and A.T.M. performed data extraction. W.C.M., C.H.B., P.R.H., M.F., J.F.C., and A.T.M. contributed analysis of the data. A.T.M. wrote the initial draft of the manuscript and W.C.M. made critical contributions to the writing of the paper. All authors reviewed and edited the manuscript and approved the final manuscript.

\section{Funding}

This work was supported by NIH grant P50 AG005138. The Icahn School of Medicine at Mount Sinai provided access to library resources. The funders had no role in the design of the study or in the collection or interpretation of the data.

\section{Availability of data and materials}

All data analyzed during this study are included in this published article and its supplementary information files. The code used to generate Fig. 2 is available at https://github.com/andymckenzie/HBPF_Review.

Ethics approval and consent to participate Not applicable. 


\section{Consent for publication}

Not applicable.

\section{Competing interests}

The authors declare that they have no competing interests.

\section{Author details}

${ }^{1}$ Department of Psychiatry, Icahn School of Medicine at Mount Sinai, One Gustave L. Levy Place, New York, NY 10029, USA. ²Department of Pathology, Icahn School of Medicine at Mount Sinai, One Gustave L. Levy Place, New York, NY 10029, USA. ${ }^{3}$ Graduate School of Biomedical Sciences, Icahn School of Medicine at Mount Sinai, One Gustave L. Levy Place, New York, NY 10029, USA. ${ }^{4}$ Gustave L. and Janet W. Levy Library, Mount Sinai Health System, One Gustave L. Levy Place, New York, NY 10029, USA. ${ }^{5}$ Nash Family Department of Neuroscience, Icahn School of Medicine at Mount Sinai, One Gustave L. Levy Place, New York, NY 10029, USA. ${ }^{6}$ Friedman Brain Institute and Ronald M. Loeb Center for Alzheimer's Disease, Icahn School of Medicine at Mount Sinai, One Gustave L. Levy Place, New York, NY 10029, USA. ${ }^{7}$ Neuropathology Brain Bank and Research Core, Icahn School of Medicine at Mount Sinai, One Gustave L. Levy Place, New York, NY 10029, USA.

\section{Received: 25 July 2019 Accepted: 26 August 2019}

\section{Published online: 05 September 2019}

\section{References}

1. Adickes ED, Folkerth RD, Sims KL (1997) Use of perfusion fixation for improved neuropathologic examination. Arch Pathol Lab Med. 121:1199-1206

2. Adickes ED, Sims KL (1996) Enhancing autopsy performance and reporting A system for a 5-day completion time. Arch Pathol Lab Med 120:249-253

3. Alvernia JE, Pradilla G, Mertens P, Lanzino G, Tamargo RJ (2010) Latex injection of cadaver heads: technical note. Neurosurgery. 67:362-367

4. Bass BP, Engel KB, Greytak SR, Moore HM (2014) A review of preanalytical factors affecting molecular, protein, and morphological analysis of formalin-fixed, paraffin-embedded (FFPE) tissue: how well do you know your FFPE specimen? Arch Pathol Lab Med. 138:1520-1530

5. Bauer DR, Stevens B, Chafin D, Theiss AP, Otter M (2016) Active monitoring of formaldehyde diffusion into histological tissues with digital acoustic interferometry. J Med Imaging 3. Article number: 017002

6. Beach TG, Adler CH, Sue LI, Serrano G, Shill HA, Walker DG et al (2015) Arizona study of aging and neurodegenerative disorders and brain and body donation program. Neuropathology. 35:354-389

7. Beach TG, Tago H, Nagai T, Kimura H, McGeer PL, McGeer EG (1987) Perfusion-fixation of the human brain for immunohistochemistry: comparison with immersion-fixation. J Neurosci Methods 19:183-192

8. Bellier A, Chanet A, Belingheri P, Chaffanjon P (2018) Techniques of cadaver perfusion for surgical training: a systematic review. Surg Radiol Anat 40:439-448

9. Benet A, Rincon-Torroella J, Lawton MT, Sánchez JJG (2014) Novel embalming solution for neurosurgical simulation in cadavers: laboratory investigation. J Neurosurg 120:1229-1237

10. Berretta S, Heckers S, Benes FM (2015) Searching human brain for mechanisms of psychiatric disorders. Implications for studies on schizophrenia. Schizophr Res 167:91

11. Bodian D (1936) A new method for staining nerve fibers and nerve endings in mounted paraffin sections. Anat Rec 65:89-97

12. Böhm E (1983) A preparative technique for morphological analysis of the vessels in head and neck for medico-legal examinations. Scan Electron Microsc: (4):1973-1981

13. Bone Q, Denton EJ (1971) The osmotic effects of electron microscope fixatives. J Cell Biol 49:571-581

14. Bullock GR (1984) The current status of fixation for electron microscopy: a review. J Microsc 133:1-15

15. Carlos AF, Poloni TE, Medici V, Chikhladze M, Guaita A, Ceroni M (2019) From brain collections to modern brain banks: a historical perspective. Alzheimers Dement Transl Res Clin Interv 5:52-60

16. Carson FL, Martin JH, Lynn JA (1973) Formalin fixation for electron microscopy: a re-evaluation. Am J Clin Pathol 59:365-373

17. Chang LW, Slikker W (1995) Neurotoxicology: approaches and methods. San Diego: Academic Press

18. Chu W-S, Furusato B, Wong K, Sesterhenn IA, Mostofi FK, Wei MQ et al (2005) Ultrasound-accelerated formalin fixation of tissue improves morphology, antigen and mRNA preservation. Mod Pathol Off J U S Can Acad Pathol Inc 18:850-863

19. Connolly AJ, Finkbeiner WE, Ursell PC, Davis RL. Chapter 8 - microscopic examination. In: Connolly AJ, Finkbeiner WE, Ursell PC, Davis RL, editors. Autopsy Pathol man atlas Third Ed. Philadelphia: Elsevier; 2016. p. 90-107

20. Coveñas R, Martin F, Belda M, Smith V, Salinas P, Rivada E et al (2003) Mapping of neurokinin-like immunoreactivity in the human brainstem. BMC Neurosci 4:3

21. Dawe RJ, Bennett DA, Schneider JA, Vasireddi SK, Arfanakis K (2009) Postmortem MRI of human brain hemispheres: T2 relaxation times during formaldehyde fixation. Magn Reson Med 61:810-818

22. de Oliveira KC, Grinberg LT, Hoexter MQ, Brentani H, Suemoto CK, Nery FG et al (2019) Layer-specific reduced neuronal density in the orbitofrontal cortex of older adults with obsessive-compulsive disorder. Brain Struct Funct 224:191-203

23. de Oliveira KC, Nery FG, REL F, Lima MC, Cappi C, Machado-Lima A et al (2012) Brazilian psychiatric brain bank: a new contribution tool to network studies. Cell Tissue Bank 13:315-326

24. Donckaster G, Politoff A (1963) Perfusion and fixation "in situ" of the brain: its usefulness in neuropathology. Neurocirugia. 21:20-23

25. Eichhammer $P$, Zeller R, Rohkamm R (1987) Fixation of neural tissue for electron microscopy with an electronically controlled perfusion pump. Tissue Cell 19:153-157

26. Eltoum I, Fredenburgh J, Myers RB, Grizzle WE (2001) Introduction to the theory and practice of fixation of tissues. J Histotechnol 24:173-190

27. Estrada LI, Robinson AA, Amaral AC, Giannaris EL, Heyworth NC, Mortazavi F et al (2017) Evaluation of long-term cryostorage of brain tissue sections for quantitative histochemistry. J Histochem Cytochem 65:153-171

28. Feekes JA, Hsu S-W, Chaloupka JC, Cassell MD (2005) Tertiary microvascular territories define lacunar infarcts in the basal ganglia. Ann Neurol 58:18-30

29. Fix AS, Garman RH (2000) Practical aspects of neuropathology: a technical guide for working with the nervous system. Toxicol Pathol 28:122-131

30. Gage GJ, Kipke DR, Shain W (2012) Whole animal perfusion fixation for rodents. J Vis Exp JoVE 65. Article number: e3564

31. Garman RH (1990) Artifacts in routinely immersion fixed nervous tissue. Toxicol Pathol 18:149-153

32. Giannini C, Okazaki H (2009) Nervous system. In: Waters BL (ed) Handb autopsy Pract. Humana Press, Totowa, NJ, pp 51-68

33. Gnanakumar S, Kostusiak M, Budohoski KP, Barone D, Pizzuti V, Kirollos R et al (2018) Effectiveness of cadaveric simulation in neurosurgical training: a review of the literature. World Neurosurg 118:88-96

34. Grinberg LT, Amaro E, Teipel S, dos Santos DD, Pasqualucci CA, Leite REP et al (2008) Assessment of factors that confound MRI and neuropathological correlation of human postmortem brain tissue. Cell Tissue Bank 9:195-203

35. Halliday GM, Li YW, Joh TH, Cotton RG, Howe PR, Geffen LB et al (1988) Distribution of substance P-like immunoreactive neurons in the human medulla oblongata: co-localization with monoamine-synthesizing neurons. Synapse. 2:353-370

36. Hansma P, Powers S, Diaz F, Li W (2015) Agonal thrombi at autopsy. Am J Forensic Med Pathol 36:141-144

37. Hayat MA (1981) 2 - Factors affecting the quality of fixation. In: Hayat MA (ed) Fixat Electron Microsc. New York: Academic Press, pp 9-63

38. Heslinga FJ, Deierkauf FA (1961) The action of histological fixatives on tissue lipids. Comparison of the action of several fixatives using paper chromatography. J Histochem Cytochem Off J Histochem Soc 9:572-577

39. Hobro AJ, Smith NI (2017) An evaluation of fixation methods: spatial and compositional cellular changes observed by Raman imaging. Vib Spectrosc 91:31-45

40. Huang XF, Paxinos G, Halasz P, McRitchie D, Törk I (1993) Substance P- and tyrosine hydroxylase-containing neurons in the human dorsal motor nucleus of the vagus nerve. J Comp Neurol 335:109-122

41. Ilinsky I, Horn A, Paul-Gilloteaux P, Gressens P, Verney C, Kultas-llinsky K (2018) Human motor thalamus reconstructed in 3D from continuous sagittal sections with identified subcortical afferent territories. eNeuro 5 ENEURO.0060-18.2018

42. Insausti R, Tuñón T, Sobreviela T, Insausti AM, Gonzalo LM (1995) The human entorhinal cortex: a cytoarchitectonic analysis. J Comp Neurol 355:171-198

43. Istomin AA (1994) The use of perfusion for brain fixation. Arkh Patol 56:78-79

44. Jortner BS (2006) The return of the dark neuron. A histological artifact complicating contemporary neurotoxicologic evaluation. Neurotoxicology. 27:628-634 
45. Kalimo H, Garcia JH, Kamijyo Y, Tanaka J, Viloria JE, Valigorsky JM et al (1974) Cellular and subcellular alterations of human CNS: studies utilizing in situ perfusion fixation at immediate autopsy. Arch Pathol 97:352-359

46. Kawamata T, Mori T, Sato S, Katayama Y (2007) Tissue hyperosmolality and brain edema in cerebral contusion. Neurosurg Focus 22:E5

47. Kiernan JA (2000) Formaldehyde, formalin, paraformaldehyde and glutaraldehyde: what they are and what they do. Microsc Today 8:8-13

48. Koenig H, Groat RA, Windle WF (1945) A physiological approach to perfusion-fixation of tissues with formalin. Stain Technol 20:13-22

49. Kretzschmar H (2009) Brain banking: opportunities, challenges and meaning for the future. Nat Rev Neurosci 10:70-78

50. Lamberts R, Goldsmith PC (1986) Fixation, fine structure, and immunostaining for neuropeptides: perfusion versus immersion of the neuroendocrine hypothalamus. J Histochem Cytochem Off J Histochem Soc. 34:389-398

51. Lang GE, Stewart PS, Vella D, Waters SL, Goriely A (2014) Is the Donnan effect sufficient to explain swelling in brain tissue slices? J R Soc Interface 11:20140123

52. Lascano EF (1958) A glycine-Hcl-formalin fixative for improved staining of neuroglia. Stain Technol 33:9-14

53. Latini F, Hjortberg M, Aldskogius $H$, Ryttlefors M (2015) The use of a cerebral perfusion and immersion-fixation process for subsequent white matter dissection. J Neurosci Methods 253:161-169

54. Lavenex P, Lavenex PB, Bennett JL, Amaral DG (2009) Postmortem changes in the neuroanatomical characteristics of the primate brain: hippocampal formation. J Comp Neurol 512:27-51

55. Liebeskind David S (2003) Collateral circulation. Stroke. 34:2279-2284

56. Liersch-Nordqvist A, Fakhro M, Pierre L, Hlebowicz J, Malmsjo M, Ingemansson $R$ et al (2017) The impact of alteplase on pulmonary graft function in donation after circulatory death - an experimental study. Ann Med Surg 22:1-6

57. Lin JX, Tomimoto H, Akiguchi I, Matsuo A, Wakita H, Shibasaki $H$ et al (2000) Vascular cell components of the medullary arteries in Binswanger's disease brains: a morphometric and immunoelectron microscopic study. Stroke. 31:1838-1842

58. Lyck L, Dalmau I, Chemnitz J, Finsen B, Schrøder HD (2008) Immunohistochemical markers for quantitative studies of neurons and glia in human neocortex. J Histochem Cytochem 56:201-221

59. Masawa N, Suzuki K, Joshita T (1993) Morphometry of medial necrosis of human intracerebral arteries. Med Electron Microsc 26:185-190

60. Masawa N, Yoshida Y, Yamada T, Joshita T, Sato S, Mihara B (1994) Morphometry of structural preservation of tunica media in aged and hypertensive human intracerebral arteries. Stroke. 25:122-127

61. Maunsbach A, Afzelius B (1999) Biomedical electron microscopy. San Diego: Academic Press

62. McGeer PL, Itagaki S, McGeer EG (1988) Expression of the histocompatibility glycoprotein HLA-DR in neurological disease. Acta Neuropathol (Berl) 76:550-557

63. McIntyre RL, Fahy GM (2015) Aldehyde-stabilized cryopreservation. Cryobiology. 71:448-458

64. McKenzie JC, Berman NE, Thomas CR, Young JK, Compton LY, Cothran LN et al (1994) Atrial natriuretic peptide-like (ANP-LIR) and ANP prohormone immunoreactive astrocytes and neurons of human cerebral cortex. Glia. 12:228-243

65. Meissner DH, Schwarz H (1990) Improved cryoprotection and freeze-substitution of embryonic quail retina: a TEM study on ultrastructural preservation. J Electron Microsc Tech 14:348-356

66. Miller DC (1998) Use of perfusion fixation for improved neuropathologic examination. Arch Pathol Lab Med. 122:949

67. Morin F, Crevier C, Bouvier G, Lacaille JC, Beaulieu C (1997) A fixation procedure for ultrastructural investigation of synaptic connections in resected human cortex. Brain Res Bull 44:205-210

68. Nacul L, O'Donovan DG, Lacerda EM, Gveric D, Goldring K, Hall A et al (2014) Considerations in establishing a post-mortem brain and tissue bank for the study of myalgic encephalomyelitis/chronic fatigue syndrome: a proposed protocol. BMC Res Notes 7:370

69. Nakamura S, Kawamata T, Yasuhara O, Akiguchi I, Kimura J, Kimura H et al (1991) The histochemical demonstration of monoamine oxidase-containing neurons in the human hypothalamus. Neuroscience. 44:457-463

70. Pakkenberg $H$ (1966) The number of nerve cells in the cerebral cortex of man. J Comp Neurol 128:17-19

71. Palay SL, SM MG-R, Gordon S, Grillo MA (1962) Fixation of neural tissues for electron microscopy by perfusion with solutions of osmium tetroxide. J Cell Biol 12:385-410
72. Park Y-G, Sohn CH, Chen R, McCue M, Yun DH, Drummond GT et al (2019) Protection of tissue physicochemical properties using polyfunctional crosslinkers. Nat Biotechnol 37:73-83

73. Phan T, Fong A, Donnan G, Reutens D (2007) Digital map of posterior cerebral artery infarcts associated with posterior cerebral artery trunk and branch occlusion. Stroke. 38:1805-1811

74. Rutherford RB, Jones DN, Bergentz SE, Bergqvist D, Karmody AM, Dardik H et al (1984) The efficacy of dextran 40 in preventing early postoperative thrombosis following difficult lower extremity bypass. J Vasc Surg 1:765-773

75. Ryan R, Hill S (2016) How to GRADE the quality of the evidence. Cochrane Consum Commun Group

76. Saliani A, Perraud B, Duval T, Stikov N, Rossignol S, Cohen-Adad J (2017) Axon and myelin morphology in animal and human spinal cord. Front Neuroanat 11

77. Schultz RL, Karlsson U (1965) Fixation of the central nervous system for electron microscopy by aldehyde perfusion: II. Effect of osmolarity, pH of perfusate, and fixative concentration. J Ultrastruct Res 12:187-206

78. Shaikh R, Sohail S (2018) MRA-based evaluation of anatomical variation of circle of Willis in adult Pakistanis. J Pak Med Assoc 68:187-191

79. Sharma M, Grieve JHK (2006) Rapid fixation of brains: a viable alternative? J Clin Pathol 59:393-395

80. Sheedy D, Garrick T, Dedova I, Hunt C, Miller R, Sundqvist N et al (2008) An Australian brain Bank: a critical investment with a high return! Cell Tissue Bank 9:205-216

81. Shinkai H, Yoshida Y, Ooneda G (1976) An electron microscopic study of plasmatic arterionecrosis in the human cerebral arteries. Virchows Arch A Pathol Anat Histol. 369:181-190

82. Somogyi P, Takagi H (1982) A note on the use of picric acidparaformaldehyde-glutaraldehyde fixative for correlated light and electron microscopic immunocytochemistry. Neuroscience. 7:1779-1783

83. Sorrells SF, Paredes MF, Cebrian-Silla A, Sandoval K, Qi D, Kelley KW et al (2018) Human hippocampal neurogenesis drops sharply in children to undetectable levels in adults. Nature. 555:377-381

84. Stuart D, Christian R, Uschmann H, Palokas M (2018) Effectiveness of intrathecal nicardipine on cerebral vasospasm in non-traumatic subarachnoid hemorrhage: a systematic review. JBI Database Syst Rev Implement Rep 16:2013-2026

85. Sutoo D, Akiyama K, Yabe K, Kohno K (1994) Quantitative analysis of immunohistochemical distributions of cholinergic and catecholaminergic systems in the human brain. Neuroscience. 58:227-234

86. Suzuki K, Hori S, Ooneda G (1979) Electron microscopic study on the medial defect at the apex of human cerebral arterial bifurcations. Virchows Arch A Pathol Anat Histol 382:151-161

87. Tanaka J, Garcia JH, Max SR, Viloria JE, Kamijyo Y, McLaren NK et al (1975) Cerebral sponginess and GM3 gangliosidosis; ultrastructure and probable pathogenesis. J Neuropathol Exp Neurol 34:249-262

88. Thavarajah R, Mudimbaimannar VK, Elizabeth J, Rao UK, Ranganathan K (2012) Chemical and physical basics of routine formaldehyde fixation. J Oral Maxillofac Pathol JOMFP 16:400-405

89. Toga AW, Ambach K, Quinn B, Hutchin M, Burton JS (1994) Postmortem anatomy from cryosectioned whole human brain. J Neurosci Methods 54:239-252

90. Torack RM, Morris JC (1990) Tyrosine hydroxylase-like (TH) immunoreactivity in human mesolimbic system. Neurosci Lett 116:75-80

91. Tufanaru C, Munn Z, Aromataris E, Campbell J, Hopp L (2017) Chapter 3: systematic reviews of effectiveness. Joanna Briggs Inst Rev Man Joanna Briggs Inst

92. Turkoglu E, Seckin H, Gurer B, Ahmed A, Uluc K, Pulfer K et al (2014) The cadaveric perfusion and angiography as a teaching tool: imaging the intracranial vasculature in cadavers. J Neurol Surg Part B Skull Base 75:435-444

93. von Keyserlingk D, Schramm U (1984) Diameter of axons and thickness of myelin sheaths of the pyramidal tract fibres in the adult human medullary pyramid. Anat Anz 157:97-111

94. Vonsattel JPG, del Pilar Amaya M, Cortes EP, Mancevska K, Keller CE (2008) 21 st century brain banking practical prerequisites and lessons from the past: the experience of New York Brain Bank - Taub Institute - Columbia University. Cell Tissue Bank 9:247-258

95. Waldvogel HJ, Bullock JY, Synek BJ, Curtis MA, van Roon-Mom WMC, Faull RLM (2008) The collection and processing of human brain tissue for research. Cell Tissue Bank 9:169-179

96. Waldvogel HJ, Curtis MA, Baer K, Rees MI, Faull RLM (2006) Immunohistochemical staining of post-mortem adult human brain sections. Nat Protoc 1:2719-2732 
97. Wang X, Allen WE, Wright MA, Sylwestrak EL, Samusik N, Vesuna S et al (2018) Three-dimensional intact-tissue sequencing of single-cell transcriptional states. Science. Vol. 361. Article number: eaat5691.

98. Wangensteen D, Bachofen H, Weibel ER (1981) Effects of glutaraldehyde or osmium tetroxide fixation on the osmotic properties of lung cells. J Microsc 124:189-196

99. Welikovitch LA, Do Carmo S, Maglóczky Z, Szocsics P, Lőke J, Freund T et al (2018) Evidence of intraneuronal $A \beta$ accumulation preceding tau pathology in the entorhinal cortex. Acta Neuropathol (Berl). 136:901-917

100. Willaert W, Tozzi F, Van Herzeele I, D'Herde K, Pattyn P (2018) Systematic review of surgical training on reperfused human cadavers. Acta Chir Belg 118:141-151

101. Xu CS, Hayworth KJ, Lu Z, Grob P, Hassan AM, García-Cerdán JG et al (2017) Enhanced FIB-SEM systems for large-volume 3D imaging. eLife. 6:e25916

102. Zaninovich OA, Ramey WL, Walter CM, Dumont TM (2017) Completion of the circle of Willis varies by gender, age, and indication for computed tomography angiography. World Neurosurg. 106:953-963

\section{Publisher's Note}

Springer Nature remains neutral with regard to jurisdictional claims in published maps and institutional affiliations.

Ready to submit your research? Choose BMC and benefit from:

- fast, convenient online submission

- thorough peer review by experienced researchers in your field

- rapid publication on acceptance

- support for research data, including large and complex data types

- gold Open Access which fosters wider collaboration and increased citations

- maximum visibility for your research: over $100 \mathrm{M}$ website views per year

At BMC, research is always in progress.

Learn more biomedcentral.com/submissions 